\title{
Las competencias artísticas en la enseñanza del arte
}

\author{
Silvia Fernández* y Gerardo Chavero** \\ CEPE-UNAM
}

\begin{abstract}
Resumen: En el presente artículo se muestran las conclusiones y acuerdos obtenidos por los maestros del departamento de Arte en el seminario "La enseñanza del Arte en el Centro de Enseñanza para Extranjeros" sobre el análisis de los lineamientos nacionales e internacionales establecidos para la educación basada por competencias y generar las competencias específicas para el departamento de Arte del CEPE. Asimismo, se incluyen aspectos relacionados con los descubrimientos neurofisiológicos del cerebro humano, con el propósito de reflexionar ciertas nociones referentes al arte.
\end{abstract}

Palabras clave: Educación basada por competencias, reforma educativa de la educación básica, multiculturalidad, interculturalidad.

\begin{abstract}
In this paper, we present the conclusions and agreements reached by the masters of the Art Department at the seminar "Teaching Art at the Center for Foreign Students" on the analysis of national and international guidelines established for competency-based education and generate specific competencies for ECE department Art. Also included aspects neurophysiological discoveries of the human brain, in order to reflect certain notions concerning the art.
\end{abstract}

Key words: competency-based education, educational reform of basic education, multiculturalism, interculturalism.

* Doctora en Historia del Arte por la Facultad de Filosofía y Letras, de la Universidad Nacional Autónoma de México, profesora de tiempo completo del Centro de Enseñanza para Extranjeros. Ha dictado conferencias, impartido cursos y dirigido diplomados en distintas universidades del país.

** Licenciado en Ciencias Políticas y Administración Pública por la Facultad de Ciencias Políticas y Sociales de la Universidad Nacional Autónoma de México. Fue investigador en la UAM-Xochimilco en la materia de desarrollo rural. Desde 1997 es profesor del Centro de Enseñanza para Extranjeros donde imparte cursos en torno al tema indígena con un enfoque intercultural. 
INTRODUCCIÓN

\begin{abstract}
“Hoy más que nunca el arte debería dar sentido a la vida, cumpliendo de modo prioritario la suprema misión de comunicar entre sí a los hombres de las diferentes razas, credos, ideologías, derribando barreras, aportando nuevas perspectivas de entendimiento y unidad entre las naciones".
\end{abstract}

(Items y de Gainza, 1994:13)

El presente documento, muestra algunos acuerdos que se tomaron de manera colegiada por los profesores del departamento de Arte del Centro de Enseñanza para Extranjeros (CEPE) de la Universidad Nacional Autónoma de México (UNAM), como resultado del seminario organizado y coordinado por la doctora Silvia Fernández "La enseñanza del arte en el Centro de Enseñanza para Extranjeros", efectuado del 31 de marzo al 16 de junio de 2009. En primera instancia, presenta una noción general de diferentes aspectos, a nivel nacional e internacional, que inciden en lo referente a la educación basada en competencias, para que de esta manera podamos desarrollar las competencias específicas para el departamento de Arte del Centro.

Una de las metas fundamentales de la unESCo ha sido la promoción de la paz y la cooperación internacional a través de la educación, la ciencia y la cultura; para garantizar el cumplimiento de los derechos humanos, la democracia y la tolerancia, ha promovido el desarrollo del concepto del "aprendizaje intercultural".

En 1990, en la Conferencia Mundial sobre "Educación para Todos" celebrada en Jomtien, Tailandia, se acordó una "visión ampliada" para satisfacer las necesidades educativas. En 1996 la Comisión Internacional sobre Educación de la unEsco para el siglo xxI, entre otros acuerdos, estableció que "la educación le permita a sus miembros adquirir un conocimiento profundo de su patrimonio cultural y de otra cultura que desee conocer". Por otro lado, en la Cumbre del Milenio 2000, los objetivos que se establecieron para el 2015 fueron el homologar la educación en un sistema internacional de una forma escalonada para alcanzar una cobertura universal. En consecuencia, a partir del 2003 el gobierno mexicano se comprometió con la unESCO para llevar a cabo a cabo una reforma educativa nacional para cumplir las metas fijadas en los acuerdos para el 2015. (sep, 2006)

De esta manera y de acuerdo con las necesidades que la educación presenta a nivel internacional, los profesores del departamento de Arte del CEPE retomando los planteamientos antes señalados, basados en nuestras particularidades específicas, así como a nuestras consideraciones y necesidades propias. Hemos elaborado de este documento, contemplando los lineamientos establecidos por la Secretaría de Educación Pública (SEP), basados en los acuerdos generales internaciona- 
les de la unEsCo. Sin embargo, al discutir sus contenidos encontramos diferencias con nuestros cursos, porque en el CEPE no enseñamos arte, sino primordialmente historia del arte; y las artes escénicas no se enseñan para formar profesionales en ellas. Asimismo, se debemos considerar que en el CEPE la enseñanza se da a un nivel universitario.

En el documento se incluyen también, algunos aspectos generales relacionados con los nuevos descubrimientos neurofisiológicos del funcionamiento del cerebro humano, con el propósito de reflexionar ciertas nociones referentes al arte, a la sensibilidad, las emociones, los sentimientos, para diferenciarlas de los procesos racionales, lógicos, matemáticos y del lenguaje. De tal forma, destacamos la importancia que tiene la experiencia sensorial para la adquisición del conocimiento; además de las vivencias que recrea el maestro para sus alumnos con el objeto de apreciar, experimentar, expresar y sentir el arte, así como los factores socioculturales con los que se interrelaciona.

\section{LAS COMPETENCIAS}

Entre los requerimientos internacionales solicitados por la unESCO para el desarrollo del Programa Internacional, se determina que por lo menos el cincuenta por ciento de los contenidos curriculares se cubran a través de la realización de unidades que respondan a las siguientes preguntas, que enfrenten a las competencias requeridas para los educandos del siglo xxl:

- ¿Quiénes somos?

- ¿Dónde nos encontramos en el tiempo y en el espacio?

- ¿Cómo nos expresamos?

- ¿Cómo funciona el mundo?

- ¿Cómo nos organizamos?

- ¿Cómo compartimos el planeta?

La reforma educativa de la educación básica de la SEP parte de la estrategia de reforma integral. (sEP. 2008: 249-257) Para conseguirlo, ha adoptado el modelo educativo basado en competencias, que responde a las necesidades sociales del desarrollo mexicano del siglo xxı.

Para que la reforma educativa, sea integral, debe aplicarse en la capacitación de los profesores, la actualización de los contenidos y programas de estudio, los nuevos enfoques pedagógicos, los métodos de enseñanza y la diversificación de los recursos didácticos. Las características sustantivas del nuevo plan de es- 
tudios del CEPE atienden a: la diversidad de los alumnos; la importancia de la interculturalidad; el énfasis en el desarrollo de competencias; la definición de los aprendizajes esperados en cada grado y asignatura; la incorporación de temas transversales, que se abordan en más de un grado y asignatura.

El enfoque de educación basado en competencias no sólo considera el desarrollo del alumno, sino que también contempla un perfil del docente:

\begin{abstract}
[...] constituido por un conjunto de competencias que integran conocimientos, habilidades y actitudes que el docente pone en juego para generar ambientes de aprendizaje para que los estudiantes desplieguen las competencias genéricas. Dicho de otra manera, estas competencias formulan las cualidades individuales, de carácter ético, académico, profesional y social que debe reunir el docente.
\end{abstract}

Las competencias docentes siguen la misma estructura que el perfil del egresado, aunque no se corresponden de forma idéntica:

- Organiza su formación continua a lo largo de su trayectoria profesional.

- Domina y estructura los saberes para facilitar experiencias de aprendizaje significativo.

- Planifica los procesos de enseñanza y de aprendizaje atendiendo al enfoque por competencias, y los ubica en contextos disciplinares, curriculares y sociales amplios.

- Lleva a la práctica procesos de enseñanza y de aprendizaje de manera efectiva, creativa e innovadora a su contexto institucional.

- Evalúa los procesos de enseñanza y de aprendizaje con un enfoque formativo.

- Construye ambientes para el aprendizaje autónomo y colaborativo.

- Contribuye a la generación de un ambiente que facilite el desarrollo sano e integral de los estudiantes.

- Participa en los proyectos de mejora continua de su escuela y apoya la gestión institucional.

Desde nuestra perspectiva, el aspecto más interesante de esta discusión es que este movimiento de la enseñanza por competencias nos ofrece una oportunidad de volver a reflexionar sobre los asuntos clave de la educación formal y nos conduce a una revisión profunda sobre las concepciones y métodos de enseñanza para buscar un cambio radical en las prácticas didácticas de los docentes. (García, 2008)

Al abordarse las competencias se deberán considerar sus tres elementos constitutivos, es decir, 1. las habilidades, 2. los conocimientos, y 3. los valores y actitudes. Así como también los llamados ejes de formación como aquellos que permiten concretar los planteamientos generales de las competencias. 
Según Perrenoud (2004) debemos entender por competencia: la capacidad de movilizar varios recursos cognitivos, habilidades y actitudes para hacer frente a un tipo de situaciones.

Por lo tanto las competencias:

- No son conocimientos, habilidades o actitudes aisladas, por el contrario, las competencias los movilizan e integran.

- Son movilizadas en situaciones únicas y específicas.

- El ejercicio de competencias pasa por operaciones complejas para realizar acciones.

- Se crean en formación, pero también en la cotidianeidad.

Bajo las consideraciones anteriores en el presente documento pretendemos precisar las competencias de la enseñanza del arte en el CEPE; centrándonos en la definición de las competencias básicas en la enseñanza del arte de los alumnos extranjeros en su aprendizaje del español como $L 2$, y cultura, en situación de inmersión; así como sobre los aspectos relacionados con dichas competencias, como son los ejes de formación; además de abordar el tema la interculturalidad como uno de los más importantes paradigmas conceptuales en la enseñanza actual.

Al discutir las tres competencias básicas propuestas por la SEP, se notó que en ellas no se toma en cuenta la historia del arte y la sociología del arte, por lo que se agregaron dos nuevas competencias para nuestras materias en el CEPE.

A los ejes de formación se les dio otro orden y secuencia, y se agregaron los que corresponden a las materias de artes escénicas.

NueVos PARADIGMAS CONCEPTUALES

Los nuevos paradigmas conceptuales en los que se han puesto atención al inicio del siglo xxı son: la globalidad y la interculturalidad. Los gobiernos de la Unión Europea y los programas educativos de la unEsco a nivel mundial, han bordado a través de ellos toda una política educativa que pretende zanjar los graves problemas de convivencia e intolerancia que han aflorado en las últimas décadas.

Podemos entender la globalización de la siguiente manera:

[Como] una etapa histórica configurada en la segunda mitad del siglo XX, en la cual la convergencia de procesos económicos, financieros, comunicacionales y migratorios acentúa la interdependencia entre vastos sectores de muchas sociedades y genera nuevos flujos y estructuras de interconexión supranacional. (García Canclini, 2005: 63) 
Circulan muchas metáforas respecto de la globalización que resultan utópicas, porque no logran integrar los modelos del pensamiento con la realidad de lo que significa la modificación de las identidades y de los patrones culturales de millones de personas, o las realidades subjetivas de los emigrantes, la separación de familias de pueblos enteros. Si analizamos el problema con mayor detenimiento, nos percatamos de que sólo una porción del mundo -el financiero-político-, piensa en un mundo de globalización circular; los demás la concebimos como una globalización tangencial, por el hecho real de la desigualdad en el acceso a lo que se considera una economía y una cultura global. (63)

La interculturalidad y la migración son procesos que han existido en toda la historia de la humanidad. Se puede afirmar que todas las culturas han tomado unas de otras para su desarrollo; por ello, es importante distinguir en qué consiste la diferencia entre los procesos de intercambios culturales del pasado con el fenómeno actual. La interculturalidad en la era de la globalización se refiere a la aceleración cuantitativa y cualitativa de la confrontación que supone la diversidad cultural en la convivencia diaria a nivel mundial.

Indudablemente, la globalización de los medios de comunicación y la industria de la cultura han modificado la percepción que tenemos del espacio geográfico y la identidad nacional. Las megaciudades — como la ciudad de México-, han visto diluir sus "valores nacionales" por los nuevos sincretismos culturales que se forman con la interacción de los medios de información y la tecnología, en donde la homogeneidad de la identidad de un país se construye no sólo con los símbolos culturales locales o nacionales, sino también con los transnacionales. Sin embargo, la nueva articulación entre lo local, lo nacional y lo global se presenta con rasgos diferentes en las distintas capitales cosmopolitas globalizadas de Europa, Asia, Norteamérica y América Latina. Es por ello que se requiere de una definición precisa y propia de lo que los maestros del departamento de Arte del CEPE entendemos por multiculturalidad e interculturalidad.

El punto de partida para nuestras clases en el CEPE es el conocer el interés de nuestros alumnos, teniendo en cuenta lo que la sociedad global les pide. Resulta útil el esquema de José Gimeno Sacristán (2002: 30) que resume los ejes del cambio en el escenario del mundo actual véase figura 1.

\section{MULTICULTURALIDAD E INTERCULTURALIDAD ${ }^{1}$}

La noción de multiculturalidad o diversidad cultural implica comprender que ninguna sociedad es homogénea, y mucho menos una nación como México

1 Texto elaborado por el profesor Gerardo Chavero. 


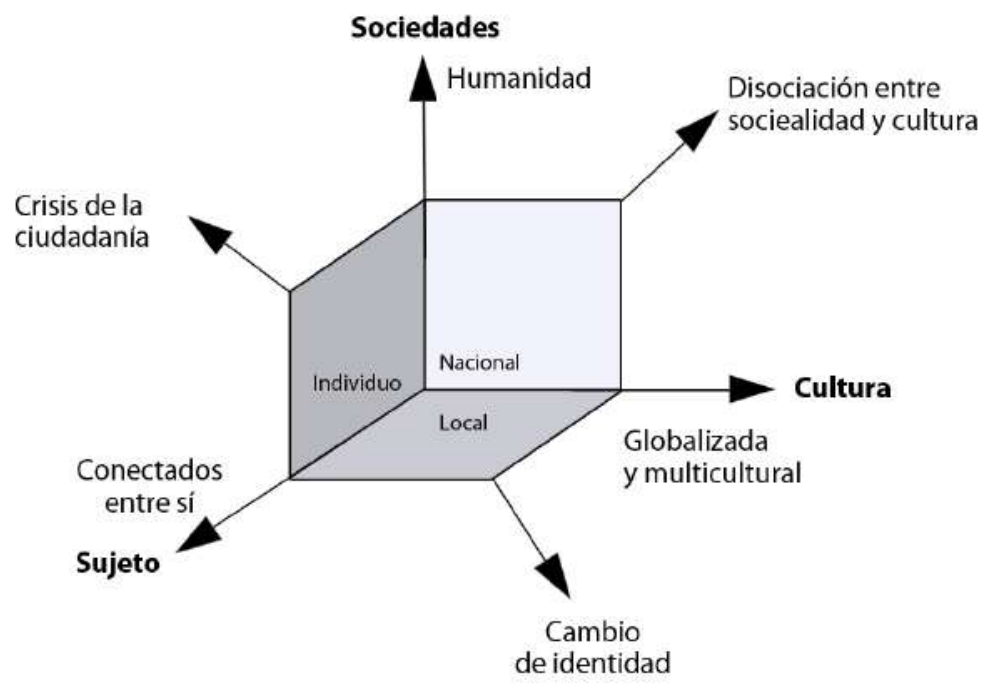

Fig. 1 Ejes de cambio en el mundo actual.

conformada por una gran variedad de culturas. Al reconocer a México como una nación pluriétnica $y$, por ende, multicultural, se entiende que en consecuencia lo heterogéneo, lo diverso, es una realidad que la caracteriza, por lo que resulta de fundamental importancia tomar en consideración en los diferentes aspectos de la vida nacional.

La educación no puede ser ajena a esta realidad, por lo que debe incluir la noción de multiculturalidad en la planeación académica, a fin de cumplir su tarea de coadyuvar en la construcción del conocimiento y del desarrollo individual y social. Sin embargo, el sólo reconocimiento de la diversidad cultural no es suficiente, se requiere del respeto que es el principio fundamental para una relación constructiva entre las diferentes culturas:

[...] La igualdad de dignidad de todos los seres humanos se basa en el respeto a las diferencias y a las peculiaridades colectivas, que a su vez están vinculadas con el derecho de tales colectividades a la sobrevivencia [...] una de las principales demandas de las sociedades multiculturales de nuestro tiempo es justamente una política explícita de reconocimiento del pluralismo cultural inherente a las sociedades, la cual implica, más que en ninguna otra época, dignificar las tareas necesarias que conduzcan al pleno reconocimiento de la diversidad humana y con ello a la resignificación de las mismas sociedades multiculturales. (Valencia, 2009: 3-4)

De lo anterior se desprende que si la multiculturalidad implica la coexistencia de diversas culturas, necesariamente se da en un contexto de interrelación, esto es, de intercambios históricos constantes, o lo que es lo mismo, de interculturalidad: 
La diversidad cultural alude como concepto a una relación social, a las formas de articulación específicas que se dan entre grupos cuya conciencia de identidad se finca en aspectos de orden cultural, sean estos los que sean. (Del Val, 2009: 1)

Concebimos la diferencia cultural no como un mal social, sino como una realidad positiva, asimismo, consideramos que la relación recíproca entre las diferentes culturas es enriquecedora, por lo cual no necesariamente implica un daño a sus identidades, por el contrario, si se concreta en un marco de relación intercultural consciente, crítico y respetuoso puede derivar en beneficios de enriquecimiento mutuo.

Aceptar con sencillez que todos los seres humanos somos diferentes y que la igualdad sólo es posible como voluntad compartida, sería tal vez un mejor camino para empezar a entender los fenómenos de la diversidad cultural. No sólo entender las determinaciones de la diversidad cultural, sino iniciar caminos nuevos en las relaciones sociales que [...] acepte[n] y respete[n] la diferencia como valor social en sí misma. (4)

Esta debe ser precisamente la labor de la educación intercultural: acercar a las diferentes culturas e individuos, acercar a los diversos, en un marco respetuoso y equitativo con el propósito de conseguir un intercambio que acorte las distancias "poniéndolas en una relación de diálogo recíproco, evitando el asimilacionismo unilateral forzado y el rupturismo cultural fragmentador". (Sacristán, 2002: 94) Por lo que entendemos que

[...] el conocimiento [por lo menos parcial] del otro es posible como el resultado de una relación social en la que ambas partes participan y comprenden simultáneamente. (Del Val, 2009: 5)

La educación intercultural tampoco es "conservacionista", ya que en el caso específico de la relación con las culturas indígenas no pretende conservarlas aisladas y estáticas, sino hacer transformaciones en su identidad cultural; pues las culturas y las identidades son realidades vivas y cambiantes, que se van adaptando al entorno histórico económico, político y social, y, por ende, a sus propias necesidades de sobrevivencia. Por supuesto, dicha transformación debe ser una transformación que surja como una construcción consciente y crítica desde sí mismas, en sus relaciones endógenas (entre sus miembros) y exógenas (con otras culturas); $y$, al mismo tiempo, entre los elementos del pasado identitario, y el presente actualizador y reconstructor dinámico de su propia identidad:

La educación intercultural [...] en lugar de proponer el retorno forzado a un pasado idealizado o a una esencia cultural abstracta, se propondría mejorar la calidad de los intercambios y la simetría de los contactos. (Tubino, 2005: 88) 
Y en el diálogo y relación entre culturas diferentes, la educación intercultural más que la "tolerancia" lo que busca es el reconocimiento, valoración y respeto del "otro", del "diferente", a fin de generar relaciones de equidad. Pues la mera tolerancia en lugar de favorecer el diálogo, "genera sociedades paralelas. [...] En la educación intercultural lo que se busca es mejorar la calidad de la convivencia, que es bastante más que la simple tolerancia". (94)

La educación intercultural favorece el fortalecimiento de las identidades, pero no de manera cerrada, sino en diálogo permanente con "el otro", buscando el intercambio de conocimientos, experiencias y vivencias; lo cual no sólo beneficia al individuo sino que repercute en un beneficio social amplio. En este sentido, se busca un equilibrio entre el respeto a los valores y derechos de los individuos, y los de la comunidad. Con esto se pretende desarrollar personas conscientes de su propio valor individual, al mismo tiempo solidarias y respetuosas de su responsabilidad y compromiso social.

Por último, al favorecerse el acercamiento, reconocimiento, valoración, respeto, diálogo e intercambio entre los diferentes, entre las diversas culturas, la educación intercultural contribuye, en su proceso formativo y transformativo, ${ }^{2}$ en la disminución de los prejuicios, estereotipos y estigmatizaciones sociales, así como de la discriminación cultural y de la discriminación en todas sus formas. (Véase Anexo 2. Ejemplo 1).

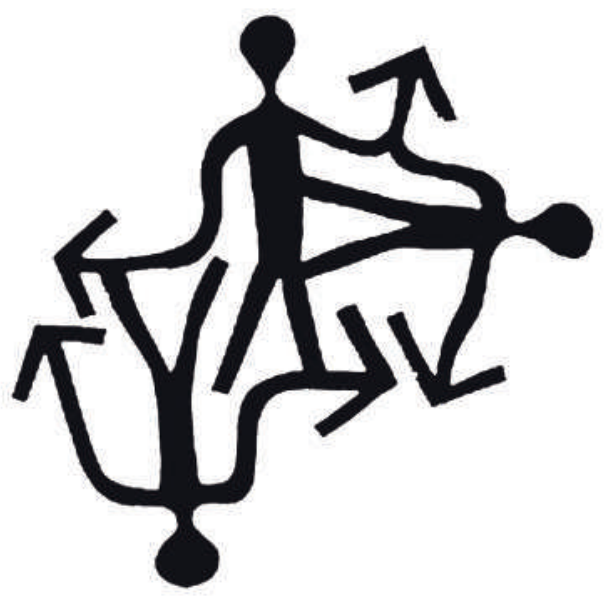

Fig. 2 llustración de Philip Meggs.

2 Se entiende por "transformativo", que tiene virtud o fuerza para transformar. (Gran Diccionario Enciclopédico llustrado, 1975). 
El siglo xxı se ha denominado "la sociedad del conocimiento", por su enorme patrimonio cultural; conocimientos que demandan múltiples y nuevas competencias en el educando, que una institución de carácter internacional no puede soslayar. Esto significa una serie de retos que los profesores del departamento de Arte deben enfrentar, como el conocimiento y manejo de los nuevos paradigmas conceptuales y pedagógicos, aunados a su valiosa experiencia docente.

Se espera que en los cursos de arte el alumno tenga un acercamiento a las disciplinas artísticas mexicanas, y con ello pueda conocer y tener referentes culturales, para describir su entorno por medio de las artes plásticas y escénicas; y así comprenda la importancia de los movimientos del cuerpo que le permitan expresar ideas y emociones; que identifique las cualidades básicas del sonido y ejecute ritmos por medio de la danza; que comprenda la diferencia entre el lenguaje verbal y el artístico para enriquecerlo personal y culturalmente. Que adquiera un conocimiento y valoración de nuestro arte, en el contexto del intercambio intercultural. Que desarrolle la capacidad de entender la interrelación entre las manifestaciones artísticas con los aspectos sociales y la diversidad cultural. (Giráldez, 2007: 72-73)

Las artes ofrecen la oportunidad de reflexionar sobre la manera en la que los individuos piensan y perciben el mundo, y como tal, constituyen una valiosa ayuda para apreciar los valores tanto propios como ajenos, para afrontar las relaciones interpersonales con una actitud respetuosa y para aceptar las propias identidades culturales y las diferencias desde la convicción de que la diversidad supone un enriquecimiento cultural.

LOS NUEVOS PARADIGMAS CONCEPTUALES Y PEDAGÓGICOS APLICABLES A LA ENSEÑANZA DEL ARTE EN EL CEPE

Los maestros del departamento de Arte del CEPE consideramos que los nuevos paradigmas conceptuales y pedagógicos para la enseñanza del arte a estudiantes extranjeros en un ambiente de inmersión son:

1. Interculturalidad: Implica la coexistencia de diversas culturas en un contexto de interrelación, esto es, de intercambios históricos constantes en lo económico, político, social y cultural. 


\section{Departamento de arte}

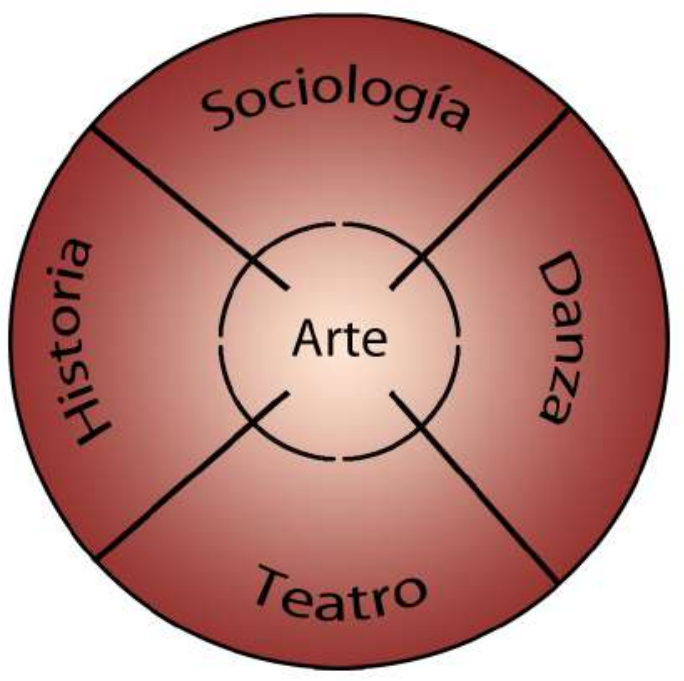

Fig. 3 Materias del departamento de Arte.

2. Competencias. Desarrollar una competencia implica:

- El saber hacer: habilidades,

- Con el saber: conocimientos.

- Así como la valoración de las consecuencias del hacer: valores y actitudes.

Se conjugan así: conocimientos, habilidades, actitudes y valores, en contextos y situaciones diversas. (SEP, 2008: 249-257)

3. Tranversalidad promueve en los alumnos la capacidad de relación y combinación entre otras asignaturas y el arte. (249-257)

4. Tecnologías de información y comunicación (TIC) La globalización demanda el manejo de las Tecnologías de Información y Comunicación escolares (TIC), como el uso del Internet, para difundir la información y los conocimientos con una mayor velocidad en la cobertura. (249-257)

5. Evaluación formativa. La función pedagógica de la evaluación formativa, debe poner atención en la calidad y proceso educativo. El maestro debe vigilar el proceso de las actividades en cada alumno y del grupo. Tanto el maestro como el alumno deben reflexionar y valorar su desempeño en las actividades. Identificar a tiempo los obstáculos para el logro de los contenidos, lo cual le permitirá al maestro modificar las formas de trabajo y adecuarlas al grupo y sus circunstancias. 
De acuerdo con lo experimentado por los docentes, se sabe que hay una relación directa entre el nivel de español y el nivel de las manifestaciones artísticas a enseñar, que varían en grados de complejidad conceptual para su apreciación. Con base en ello, entre menor nivel de español podría en ciertos casos facilitarse el utilizar un mayor número de imágenes para explicar un concepto, con ejercicios en clase que lo refuercen, aunado a lecturas adecuadas al nivel básico de español.

Para los alumnos del nivel de español intermedio, algunos profesores parten de lo general a lo particular, como sería una pequeña introducción a los alumnos en un aspecto de la apreciación del arte, como pueden ser ciertos elementos relevantes de una obra, se les enseña cómo verlos. Otros maestros parten de un tema y lo relacionan con las manifestaciones artísticas de los países de los alumnos, para examinar las diferencias entre la cultura oriental y occidental, por ejemplo. Todas las manifestaciones artísticas que se enseñan, ya sea con un método u otro, se contextualizan históricamente, para que los vean, sientan, analicen, descubran sus características y emitan una valoración estética.

En el nivel de español superior, con casi el dominio del español de los alumnos, aumentan las posibilidades de analizar las imágenes, por lo tanto, al tener ya una mayor capacidad expresiva, los alumnos deben tener una participación más directa en clase que se base en investigaciones sencillas extra clase y se orienten con las antologías preparadas por el maestro para exponer alguna obra de arte o tema del programa mediante un ensayo.

En cualquier nivel de español, las visitas guiadas son indispensables para reforzar los conocimientos y enfrentar al alumno directamente con las obras, de tal manera que pueda disfrutar su vivencia estética.

\section{LA INTERCULTURALIDAD}

Se enseña en tres niveles: 1. en el contexto histórico, 2. por medio de un intercambio intercultural simétrico, y 3 . en el conjunto de las materias que se imparten.

\section{La interculturalidad y el contexto histórico}

Los nuevos sistemas de comunicación del siglo xxı han modificado la relación entre el aquí y el allá, entre el presente, pasado y futuro; en niveles simultáneos de tiempo y espacio diferentes. El hombre del siglo xxI vive muchas realidades diferentes y heterogéneas simultáneamente. La línea divisoria entre el tiempo real, el pasado o el virtual se ha vuelto relativa, por ello es importante ubicar a los alumnos en el contexto histórico para comprender y valorar el arte y la cul- 
tura mexicanas; con la finalidad de no trivializar los ejemplos, y así los alumnos del CEPE alcancen el nivel de conocimiento y cultura que se espera de los alumnos en la unam. (Véase figura 4)

\section{Materias de Arte del CEPE}

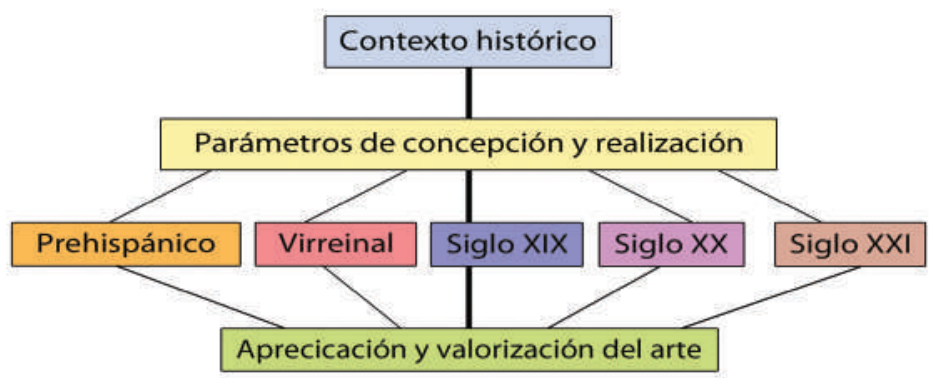

Fig. 4. Esquema de Silvia Fernández.

Elaborado por Jarumi Dávila y Roberto Muñoz.

\section{La interculturalidad y el intercambio intercultural simétrico}

La interculturalidad tiene como base el llamado intercambio intercultural-simétrico, el cual se fundamenta en el principio de equidad, esto es, sin preferencias entre las distintas manifestaciones culturales; en el caso del CEPE este intercambio se da con absoluto respeto entre las diferentes culturas de las que provienen los alumnos extranjeros. "La interculturalidad es una manera de entender y de reconstruir los procesos de socialización que se producen en contextos multiculturales asimétricos"(Turbino, 2005: 89); por tanto, la educación intercultural en el CEPE debe buscar una relación simétrica, basada en la equidad entre el profesor y alumnos.

En el arte de enseñar, para que se propicie verdaderamente el aprendizaje significativo en los alumnos, se requiere algo más que una lógica exposición de datos. El aprendizaje significativo implica involucrar a la persona con el asunto que se aprende. (Gutiérrez Sáenz, 1997: 30) 
En ocasiones, algunos docentes pretenden simplificar y reducir las innovaciones educativas con el uso de la información que proporcionan las TIc. No obstante, los nuevos paradigmas pedagógicos de las competencias y ejes de formación, deben ser entendidos como un cambio de concepción profunda en la enseñanza, que modifican los procesos de aprendizaje del alumno, la forma de planearlos y ejecutarlos, para que se convierta en un aprendizaje significativo. Un verdadero reto que ya portan las nuevas generaciones de los jóvenes extranjeros de nuestro Centro. Lo anterior se resume en el siguiente esquema.

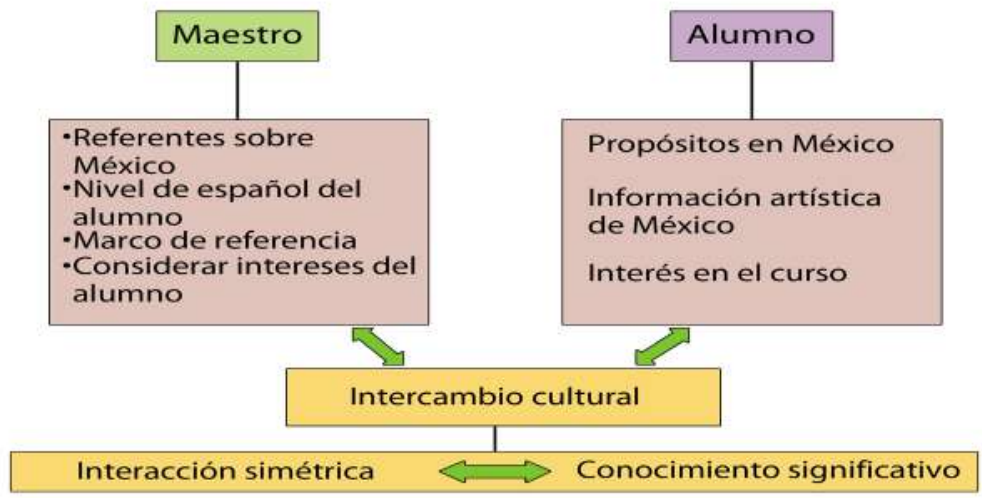

Fig. 5 Esquema de Silvia Fernández.

Elaborado por Jarumi Dávila y Roberto Muñoz.

\section{La interculturalidad en el conjunto de las materias de arte}

El departamento de Arte promueve también la interculturalidad en el conjunto de las materias que lo conforman, al enseñar al alumno la relación con la "otredad", por medio de:

- La Historia del arte. Enseña al alumno a ver al otro, a través de las obras de arte.

- Sociología del arte. Aproxima al alumno con los otros, al ponerlo en contacto directo con las personas y su cultura.

- Danza. Acerca un alumno al otro, por medio de la comunicación y movimiento corporal.

- Teatro. Enseña al alumno a "transformarse" en el otro, a través de la representación. (Véase figura 6) 


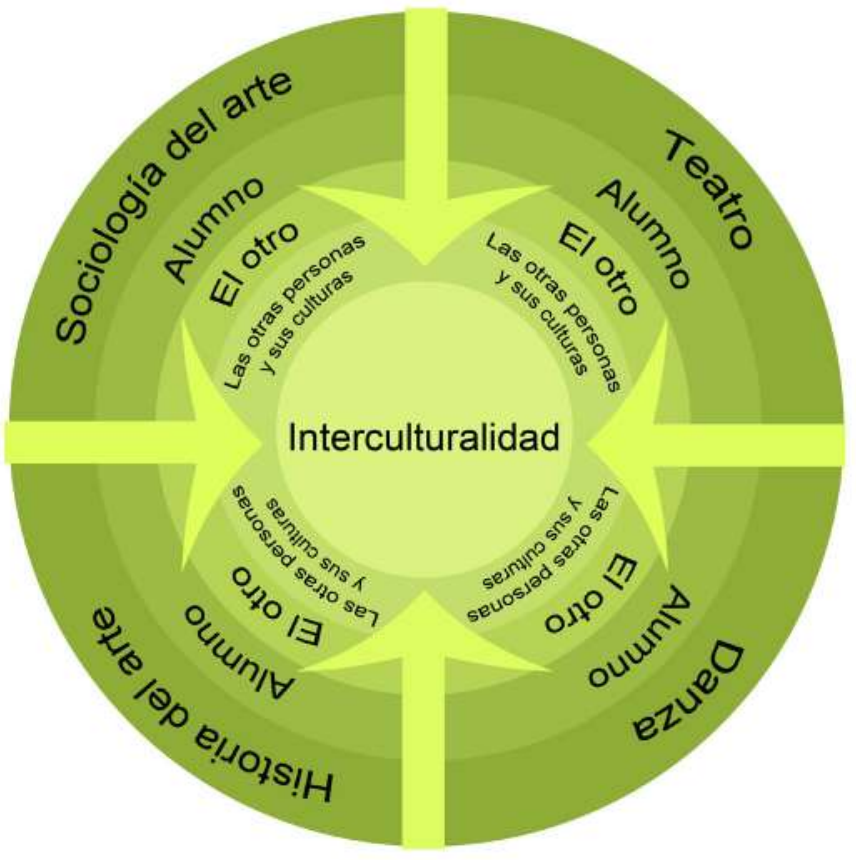

Fig. 6 Esquema de Gerardo Chavero.

Elaborado por Jarumi Dávila y Roberto Muñoz.

Entendemos por "el otro", el acercamiento o contacto que las materias de arte propician en el alumno:

- A la cultura y arte mexicanos (es "lo otro" en relación con las diversas culturas extranjeras).

- A las diversas culturas de los alumnos unas frente a otras.

- A los alumnos extranjeros frente a los alumnos mexicanos y viceversa.

- A los alumnos extranjeros frente a sus compañeros extranjeros.

- A los alumnos - tanto mexicanos como extranjeros - frente a las personas indígenas y sus culturas.

- Desde luego, el profesor también es "el otro" frente a sus alumnos.

- Asimismo, consideramos al público como "el otro" (esto en el caso de las artes escénicas).

Son dichas facetas de "otredad" o "alteridad" las que se enfrentan en clase y, por tanto, con las que las materias de arte trabajan la interculturalidad, al vincular al alumno con "el otro". (Véase Anexo 2) 
LAS COMPETENCIAS (A DESARROLLAR POR EL ALUMNO)

[Es necesario reconocer] la importancia de la educación artística, no sólo como una vía para el desarrollo integral de las personas, sino también por su potencial para afrontar los procesos de transformación por los que atraviesa la sociedad. Además, el valor de las artes en la educación debería considerarse como intrínseco a la hora de definir y promover las competencias clave necesarias para ampliar el ámbito de desarrollo personal, desarrollar habilidades interpersonales, promover el pensamiento creativo y crítico, y mejorar los resultados en otros ámbitos del aprendizaje [...] (Giráldez, 2007: 62)

Por medio de las siguientes competencias, las materias de arte desarrollan en el alumno la sensibilidad estética, humana y sociocultural (Véase figura 7):

- El pensamiento integral. Desarrolla en el alumno la capacidad de entender la vinculación entre las manifestaciones artísticas y los aspectos sociopolíticos y culturales, como fenómenos interrelacionados. ${ }^{3}$

- Percepción estética. A través de las manifestaciones artísticas, el alumno percibe sensaciones, al hacerlas conscientes les da un significado y valoración.

- Abstracción interpretativa. Es el proceso del pensamiento que permite al alumno describir, comparar, clasificar, jerarquizar, e interpretar lo que percibe para elaborar un concepto de la obra.

- Desarrolla en el alumno la congruencia entre lo que ve, siente, piensa y hace.

- Comunicación creativa. Es un proceso cognitivo y afectivo, en el que el alumno utiliza un sistema de signos para expresar sus ideas, emociones, significados y conceptos para darle sentido a lo que percibe, expresándolo verbal, gestual, corporal, visual o musicalmente.

- Revisión crítica de actitudes y valores humanos. Genera en el estudiante el cambio de actitudes frente "al otro", desarrollando el respeto a la diversidad cultural y a los derechos y valores humanos contrarios a la discriminación en todas sus formas; despertando de esta manera lo que llamamos la "sensibilidad humana".

3 Señala Andrea Giráldez (2007) que “[...] no sólo se persigue el conocimiento de diferentes códigos y manifestaciones artísticas y la utilización de técnicas y recursos que les son propios, sino que también se pretende ayudar al alumnado a adentrarse en la dimensión cultural y social del arte". (70)

4 Entendemos por "sensibilidad humana", aquella que propicia el contacto y reconocimiento con "el otro" y nos permite —al ponernos en su lugar circunstancial— "despertar" la valoración y respeto hacia la persona y su cultura. 


\section{Enfasis en el desarrollo sensible}

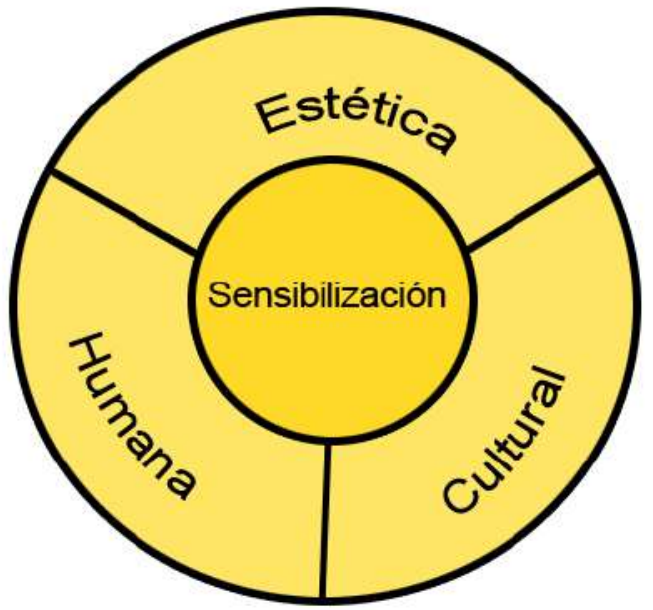

Fig. 7. Esquema Silvia Fernández.

Elaborado por Jarumi Dávila y Roberto Muñoz.

Los ejes de formación (SEP, 2008: 259-262) van de la mano de las competencias, en tanto que éstas son planteamientos generales y los ejes de formación son la forma concreta en que el maestro acerca al alumno a experimentar con las obras de arte, para comprender sus manifestaciones y que se logre el conocimiento significativo en el alumno. Por tanto, a través de los ejes de formación es posible dar aplicación concreta a las competencias; es decir, los ejes de formación son los instrumentos a través de los cuales es posible realizar las competencias:

- Contextualización. Es la ubicación de una obra de arte en su contexto histórico y cultural, para que el alumno pueda comprender los parámetros creativos de cada época.

- Observación. Es el acercamiento del alumno a la obra de arte, para que descubra sus elementos, como la composición, la forma, el color, la textura, el sonido, el movimiento, el espacio, etcétera.

- Sensibilización. Es el reconocimiento de las emociones que le produce al alumno las obras plásticas, las artes escénicas y el contacto humano. Sensibilizar es usar los sentidos y emociones en el contacto con cualquier manifestación artística y sociocultural.

- Apreciación. Valoración de las diversas expresiones artísticas en cuanto a su contenido estético, histórico, social, técnico, etcétera.

- Análisis. Es el proceso por el cual el alumno establece diferentes asociaciones con relación a la obra, al estilo, la época, el tema, al compararla, contrastarla, para comprender su grado de originalidad. 
- Asimilación. Es el proceso de aprendizaje del alumno respecto al lenguaje artístico, por medio del cual a través de las conexiones neuronales (Ilamadas sinapsis) se transmite la información al cerebro donde se almacena para fijar el aprendizaje, poder recordarlo y aplicarlo en otros momentos de su vida.

- Expresión creativa. Es la posibilidad que tiene el alumno de comunicar las vivencias que le han producido las obras de arte.

\section{EJES DE FORMACIÓN ESPECÍFICOS PARA LAS MATERIAS DE ARTES EsCÉNICAS}

- Coordinación espacio-temporal. Desarrolla en el alumno el balance entre los segmentos corporales para mantener el equilibrio, ritmo y movimiento consigo mismo y los demás.

- Mimesis. Capacidad que aprende el alumno para representar un personaje, al imitar sus gestos, movimientos, expresiones, voz, entre otros.

- Presencia escénica. Es el manejo y control de la energía corporal que aprende el alumno para desarrollar su actuación en el escenario frente al público.

¿QuÉ CAPACIDADES DESARROLLA EL ARTE?

Diversos estudios en los campos de la neurología, psicología, antropología, sociología y pedagogía, han demostrado que cuando el ser humano ejercita o disfruta de las disciplinas artísticas, despierta su capacidad para aprender y jugar libremente con los diversos lenguajes expresivos. Las artes le brindan al individuo diferentes formas de estructurar el pensamiento y las emociones; desarrollan su inteligencia; inciden en su desarrollo psicomotriz; refuerzan su capacidad de socialización, de disciplina auto conciente; y le abren la posibilidad de explorar todas sus capacidades humanas, en una formación integral, que contempla así mismo los aspectos socioculturales.

Para fundamentar con mayor exactitud a qué nos referimos con el desarrollo de las capacidades sensoriales-cognitivas de nuestros alumnos, retomamos algunos aspectos de las investigaciones de los neurólogos norteamericanos Ronald Kotulak (2003) y Richard Restack (2005).

Los especialistas nos explican que el cerebro se divide en dos partes para realizar las labores especializadas, se ha comprobado científicamente que en el lado derecho se localiza la vista, la orientación espacial y la auditiva. Del lado izquierdo se localiza el lenguaje, las matemáticas y la lógica. Ello implica que las 
materias de arte no sólo son indispensables para desarrollar las capacidades del ser humano, también establece una diferencia sustancial respecto a la enseñanza del lenguaje (del español en el caso del CEPE). Las materias de arte enseñan códigos de percepción artística y actúan sobre el lóbulo derecho; en cambio, las materias de la adquisición lingüística enseñan lenguajes completos y actúan sobre el lóbulo izquierdo.

El cerebro humano se activa y alimenta de las experiencias sensoriales del medio exterior que lo rodea. A través de los sentidos: la vista, el oído, el olfato, el tacto y el gusto, billones de conexiones de neuronas se activan o desactivan. Los estímulos visuales, auditivos, espacio-temporales y cinestésicos, de las experiencias estéticas vividas en las clases, activan las neuronas de los alumnos y les generan a su vez estímulos nuevos que los enriquecen. Las imágenes, sonidos, olores, texturas, sabores, sensaciones espaciales, táctiles y cinestésicas, el cerebro las percibe, pero las transforma, porque las clasifica y genera respuestas psicológicas emotivas.

La actividad cerebral de la expresión de las emociones del alumno en su percepción estética frente al arte debe promoverse por el docente, como parte del aprendizaje. De esta manera, las materias de arte ponen un énfasis especial en el "desarrollo sensible" del alumno, en el aspecto estético, el humano y el cultural. (Véase figura 7).

Las neuronas fijan el conocimiento por medio de la asociación en el proceso del aprendizaje, por lo tanto, esta característica se convierte en una herramienta indispensable del docente, encontrar por medio del diálogo con los estudiantes las asociaciones artísticas-sensoriales e interculturales que les permitan fijar el conocimiento de los temas del curso.

Las neuronas establecen redes de sinapsis, que es la base del aprendizaje, sin embargo, la adquisición de un nuevo conocimiento requiere de una repetición para que se consoliden las nuevas redes de las conexiones neuronales. Las preguntas, ejercicios, así como las relaciones que el docente establezca en el desarrollo de un tema ayudarán a que el alumno establezca una nueva red sináptica para conocer, aprender y quizá disfrutar del arte mexicano.

El cerebro humano tiene una enorme flexibilidad que le permite adaptarse a todo tipo de circunstancias (llamada plasticidad cerebral); sin embargo, el trabajo del docente consiste en explicar a los alumnos la aceptación de que existen diferentes realidades socio-culturales para que las comprenda. El alumno extranjero podrá adaptarse mejor durante su estancia en el país, si comprende la cultura mexicana expresada en el arte.

La neurociencia actual (en lo que tiene de exploración del cerebro) puede visualizar distintos aspectos de la actividad cerebral en personas vivas, gracias al desarrollo de nuevas tecnologías de síntesis de la imagen. La ciencia del cere- 
bro cuenta con descubrimientos precisos de los mecanismos cerebrales responsables de nuestro pensamiento, estados de ánimo, decisiones y acciones.

Con respecto a la denominada "inteligencia", no se relaciona exclusivamente con lo racional, sino que también abarca aspectos tales como la capacidad creativa, la experiencia emocional, entre otros:

Se define la cognición (inteligencia) como la capacidad del cerebro y el sistema nervioso para recibir estímulos complejos, identificarlos y actuar en consecuencia [...] Lo cual incluye actividades mentales como la alerta, la concentración, la memoria, el raciocinio, la capacidad creativa y la experiencia emocional. (Restack, 2005: 18)

Lo más acertado es considerar la inteligencia [...] y el rendimiento superior, en parte hereditaria, y en parte determinada por el medio ambiente, y por tanto modificable. Además, y puesto que son muchos los genes que configuran la estructura y el funcionamiento del cerebro [...], así como a determinar el tipo de inteligencia concreto que exhibe cada uno de ellos (compárese la inteligencia del artista con la del hombre de negocios, por ejemplo). (48-49)

Howard Gardner al comprobar con la neurociencia como el cerebro especializa sus funciones en distintas regiones que lo componen, acuñó el término de "Inteligencias múltiples" y abre un nuevo episodio en la discusión sobre los test de inteligencia, o lo que se considera por IQ, al cuestionar qué parte miden en realidad de la inteligencia. Rompe con el mito de que la inteligencia se reduce al raciocinio lógico del hemisferio izquierdo. ${ }^{5}$

El psicólogo Thorwald Dethlefsen, del Instituto de Psicología Experimental de Munich, y el doctor en medicina y psicoterapeuta Rüdiger Dahlke, nos explican las funciones específicas de los dos hemisferios cerebrales (separados y a la vez unidos por el cuerpo calloso), y de qué manera se diferencian uno del otro; lo cual nos sirve a nosotros en el departamento de Arte del CEPE -entre otras cosas-, para identificar el área cerebral dónde se localiza lo relacionado con el arte, $y$, por otro lado, diferenciar sus procesos de los referentes al lenguaje, localizado en un área cerebral distinta:

Como es sabido, el cerebro se compone de dos hemisferios unidos por el llamado cuerpo calloso [...] Con [...] experimentos, desarrollados y elaborados en los últimos tiempos, se ha recopilado información que puede condensarse así: uno y otro hemisferio se diferencian claramente por sus funciones, su capacidad y sus respectivas responsabilidades. El hemisferio izquierdo podría denominarse el <hemisferio verbal > pues es el encargado de la lógica y la estructural lenguaje, de la lectura y la escritura. Descifra analítica y racionalmente

5 Véase Howard Gardner, (1993) Multiple Intelligences: The Theory in Practice, New York: Basic Books; Howard Gardner "Cracking open the IQ Box" en The American prospect, winter, 1995; y R. Joseph (1993) The naked neurone: evolution and the languages of brain and Body, New York: Plenium Publishing, Goleman, Daniel, (2002) La inteligencia Emocional, México: Punto de lectura. 


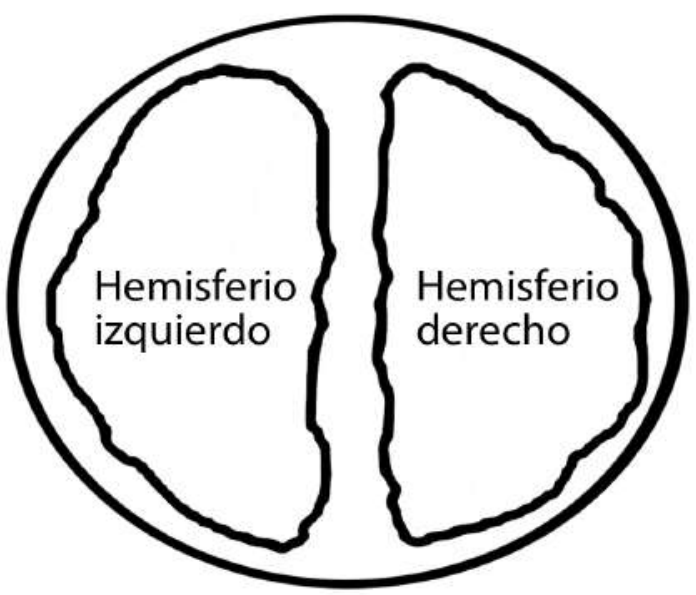

HEMISFERIO IZQUIERDO

Lógica

Lenguaje (sintaxis, gramática)
HEMISFERIO DERECHO

Percepción de las formas

Visión de conjunto

Orientación espacial

Formas de expresión arcaicas

Música

Olfato

Expresión gráfica

\author{
Noción del mundo en conjunto \\ Pensamiento analógico \\ Simbolismo \\ Intemporalidad \\ Holistica \\ Magnitudes lógicas \\ Intuición
}

Fig. 8 Hemisferios cerebrales y sus funciones. (Dethlefsen y Rüdiger, 2000: 36). ${ }^{6}$

todos los estímulos de estas áreas. Es decir, que piensa en forma digital. El hemisferio izquierdo es también el encargado del cálculo y la numeración. La noción del tiempo se alberga asimismo en el hemisferio izquierdo.

En el hemisferio derecho encontramos todas las facultades opuestas. En lugar de capacidad analítica, permite la visión de conjunto de ideas, funciones y estructuras complejas. Esta mitad cerebral permite concebir un todo (figura) partiendo de una pequeña parte (pars pro toto). Al parecer, debemos también al hemisferio cerebral derecho la facultad de concepción y estructuración de elementos lógicos (conceptos superiores, abstracciones) que no existen en la realidad. En el lóbulo derecho encontramos únicamente formas orales arcaicas que no se rigen por la sintaxis sino por esquemas de sonidos y asociaciones [...] Aquí reside también el pensamiento analógico y el arte para utilizar los símbolos. El hemisferio derecho genera también las fantasías y los sueños de la imaginación y desconoce la noción del tiempo que posee el hemisferio izquierdo.

6 No se reprodujo el esquema completo como aparece en la obra citada, sino exclusivamente la parte que sirve para los propósitos del presente documento. 
Según la actividad del individuo, domina en él uno u otro hemisferio. El pensamiento lógico, la lectura, la escritura y el cálculo exigen el predominio del hemisferio izquierdo, mientras que para escuchar música, soñar, imaginar y meditar se utiliza preferentemente el hemisferio derecho. Independientemente del predominio de un hemisferio concreto, el individuo sano dispone también de informaciones del hemisferio subordinado, ya que a través del cuerpo calloso se produce un activo intercambio de datos [...]

Es fácil imaginar lo incompleto que estaría el individuo que sólo tuviera una de las dos mitades del cerebro. Pues bien, no es más completa la noción del mundo que impera en nuestro tiempo, por cuanto que es la que corresponde a la mitad izquierda del cerebro. Desde esta única perspectiva, sólo se aprecia lo racional, concreto y analítico, fenómenos que se inscriben en la causalidad y el tiempo. Pero una noción del mundo tan [exclusivamente] racional sólo encierra media verdad, porque es la perspectiva de media conciencia, de medio cerebro. Todo el contenido de la conciencia, que la gente suele llamar con displicencia irracional, ilusorio y fantástico, no es más que la facultad del ser humano de mirar el mundo desde el polo opuesto [...] Aquí se pone de manifiesto la verdadera importancia del cuerpo calloso, el cual tiene que ser tan permeable que haga, de los <dos cerebros $>$, uno. (Dethlefsen y Rüdiger, 2000: 33-43)

LA HISTORIA DEL ARTE DE LA ARQUITECTURA, PINTURA, ESCULTURA, GRABADO, FOTOGRAFÍA, CINE Y ARTES APLICADAS ${ }^{7}$

Desarrollan la inteligencia formal-espacial ${ }^{8}$ de la persona. El alumno aprende a distinguir espacios, formas, planos, dimensiones, texturas, superficies, distancias, materiales, gamas de colores, luz y sombra, etcétera; todas ellas en su conjunto, transmiten al individuo imágenes, señales, símbolos, emociones y significados al asociar diferentes formas y colores con ideas y sentimientos. Abre la capacidad de interpretar una realidad virtual como el cine, en un ritmo y tiempo determinado. El ser humano primero mira antes de hablar; con la vista establece su lugar en el mundo que lo rodea. Las materias de arte estimulan y enseñan a ver, a clasificar, analizar, y a interpretar, lo cual es importante para que la persona pueda comprender su realidad.

Las imágenes comunican emociones. La era digital ha aumentado la calidad y cantidad de las mismas. La percepción de la imagen es más inmediata que la escrita o la oral, no se requiere de reflexión o análisis para percibirla. La imagen ha desplazado en el siglo xxı la abstracción del lenguaje por su literalidad. Las

7 Véase Anexo 1. Cuadro de habilidades cognitivas para el logro de competencias.

8 Véase lo referente a las "Inteligencias múltiples" y otros aspectos revisados en el apartado: ¿Qué capacidades desarrolla el arte? en este artículo. 
imágenes crean situaciones de verosimilitud, casi como si fuera una experiencia directa. Estas son consideraciones muy importantes para la enseñanza de la historia del arte, al recrear las emociones de una época, las vivencias estéticas en el alumno al partir de la emoción para llegar al análisis y a la reflexión.

SOCIOLOGÍA DEL ARTE ${ }^{9}$

Las materias de este rubro fomentan la inteligencia integral; ${ }^{10}$ esto es, la capacidad de visión integral, con la que el alumno logra captar los fenómenos de manera integral o interrelacionada, de tal forma que las manifestaciones artísticas las entienda no aisladas o desvinculadas, sino en relación recíproca con los aspectos sociopolíticos y culturales. Asimismo, con el principio de la interculturalidad, incorpora en los procesos de formación el respeto a la diversidad cultural, la erradicación de estereotipos sociales y la discriminación cultural. De tal forma, se logra "despertar" la "sensibilidad humana" con el respeto y valoración en el acercamiento e intercambio con "los otros"; es decir, entre los diferentes y sus diversas culturas.

ARTES ESCÉNICAS: EXPRESIÓN CORPORAL, DANZA, TEATRO ${ }^{11}$

Desarrollan la inteligencia cinestésico-corporal, ${ }^{12}$ la relación espacio temporal y la presencia escénica. ${ }^{13}$ La expresión corporal concientiza al alumno sobre la unidad cuerpo-mente (Pérez, 1997), por lo tanto aprende a usar la energía que produce su cuerpo y se concreta en movimientos y acciones para expresar ideas, emociones y estados de ánimo. La expresión corporal, coadyuva en la capacitación para el teatro y la danza. Ésta requiere también del equilibrio, desplazamiento y ritmo. Tales disciplinas amplían la coordinación corporal para la realización de movimientos en un espacio y tiempo determinados; brindan ha-

9 Texto elaborado por el profesor Gerardo Chavero, de la materia de Arte y Política de los Indígenas de la Ciudad de México.

10 Este término se acuñó basándose en la idea de las "inteligencias múltiples" y otros aspectos revisados en el apartado: ¿Qué capacidades desarrolla el arte? en este artículo.

12 Texto elaborado por la profesora Guillermina Fuentes, de las materias Expresión corporal y Teatro.

12 Véase lo referente a las "Inteligencias múltiples" y otros aspectos revisados en el apartado: ¿Qué capacidades desarrolla el arte? en este artículo.

13 La cinestesia es la relación existente entre el movimiento y la sensibilidad. En fisiología es el sentido por el que se perciben el movimiento muscular, el peso, la posición, etcétera, de nuestros miembros. Asimismo, es el estudio de las reacciones musculares y del procedimiento para educarlas. Gran Diccionario Enciclopédico Ilustrado. 
bilidades espaciales en cuanto al sentido del equilibrio, lateralidad ${ }^{14} \mathrm{y}$ motricidad. Le dan estímulos cinestésico-expresivos. Aunque en el CEPE no se enseña música, ésta va unida a la danza en cuanto que ejercita la capacidad auditiva del alumno, en el sonido y el silencio; la atención para escuchar; su coordinación psicomotora para moverse rítmicamente al mismo tiempo, y lo capacitan para relacionar la métrica del sonido y el ritmo; aumenta su memoria al recordar la secuencia del sonido y los movimientos corporales. Una capacidad del cerebro es el contagio de actitudes y emociones, como la mimesis que genera el teatro y la danza.

El teatro desarrolla también la inteligencia de la representación. ${ }^{15}$ Le brinda al alumno la oportunidad de concretar su imaginación y fantasía en un personaje o situación específica; le da un contexto lúdico para el uso de las palabras y emociones; lo concientiza para dirigirse a los demás y hacia su propia persona; le da el sentido del conjunto y de lo particular; le da la oportunidad de crear ambientes en la producción escénica. El teatro estimula su imaginación y su capacidad expresiva. Como actividad lúdica permite al alumno desarrollar la mimesis y la capacidad de representación. Al jugar y manejar su energía puede provocar sensaciones y emociones; ser "otros" (personajes) y proyectarlas a los demás (presencia escénica).

La danza ${ }^{16}$ busca desarrollar en los alumnos el placer por el movimiento, que se traduce en la comunicación de emociones a través del uso creativo del cuerpo. La pareja, los sonidos y la música son apoyos importantes para estimular el lenguaje corporal. Se trata de que los alumnos conozcan su cuerpo, lo exploren, lo acepten, lo aprecien, pero sobre todo que lo reconozcan como un medio de expresión y de comunicación. La valoración del propio cuerpo y del movimiento contribuirá a una mejor apreciación de otras formas de expresiones corporales y dancísticas.

Al propiciar una educación por el movimiento se contribuye a la formación del hombre al ejercitar una fuerte voluntad, a la maduración y desarrollo psicomotor, a la socialización humana, al rendimiento físico, hechos que exigen la constante confrontación con obstáculos y resistencias, lo que se da en forma ilustrativa cuando se practica la actividad dancística.

14 Lateralidad: Es el conjunto de predominancias de los ojos, manos y pies. De acuerdo con el desarrollo neuromotor, se establece el siguiente proceso para facilitar la orientación del cuerpo. La lateralización es el resultado de una predominancia motriz del cerebro. Presentándose sobre los segmentos corporales derecho e izquierdo, tanto a nivel de los ojos, manos y pies. La lateralización depende de dos factores: la maduración neurológica del individuo y las influencias culturales que recibe. Definición aportada por la profesora Blanca Jazmín Heredia, del curso danza tradicional.

15 Véase lo referente a las "Inteligencias múltiples" y otros aspectos revisados en el apartado: ¿Qué capacidades desarrolla el arte? en este artículo.

16 Texto elaborado por la profesora Blanca Jazmín Heredia, del curso de danza tradicional. 
Con lo anotado antes sobre las competencias que desarrolla la educación artística en el alumno, se puede aplicar la transversalidad al interrelacionar los conocimientos de arte con los de las otras disciplinas, por ejemplo:

La enseñanza del español en cuanto a:

- la comprensión del idioma español;

- el alumno puede narrar, exponer, expresar oralmente y por escrito las emociones e ideas que vive a través de la experiencia artística;

- describe imágenes;

- puede conversar sobre las lecturas asignadas;

- también incorpora a su adquisición del español términos artísticos, no solamente en un listado de vocabulario (lo cual puede hacer él solo con el diccionario), sino a través de la relación con el estilo, la época, el autor.

La enseñanza de la historia:

Porque es una parte indispensable de la contextualización de las obras de arte.

La enseñanza de la literatura:

Porque muchos literatos han teorizado y creado símbolos que se representan en esculturas, pinturas, películas, etcétera.

\section{ConClusiones}

Para el nuevo Plan de Estudios del CEPE en el que el eje es el desarrollo de la educación por competencias, el Departamento de Arte deberá contemplar las siguientes preguntas básicas:

- ¿Qué aporta el arte a la educación del alumno?

- ¿Qué tipo de relación existe entre el arte y la educación?

- ¿Cuáles y cómo se dan sus variantes?

- ¿Qué debemos enseñar y con qué fines?

- ¿Cómo organizar y diseñar el plan de estudio y los programas de enseñanza de la historia del arte, la sociología del arte y las artes escénicas en el CEPE?

- ¿Cómo implementar de manera eficaz las estrategias de transversalidad con los cursos de español? 
F. Graeme Chalmers (203), profesor de educación artística de la Universidad de Vancouver (Columbia Británica, Canadá), nos aporta algunos elementos al respecto:

[...] Hacer que la teoría sea relevante para la práctica. Con ello contribuir a que los profesores y otras personas reflexionen sobre las funciones y los roles del arte en la sociedad de manera significativa, como corresponde a una sociedad culturalmente plural. [...] en el campo del arte, tanto los programas materiales y actividades educativas como el aprendizaje artístico de los mismos estudiantes pueden contribuir a alcanzar los siguientes objetivos:

Promover la comprensión transcultural gracias a la identificación de semejanzas (especialmente roles y funciones del arte) dentro y entre diversos grupos culturales.

Reconocer, aceptar y celebrar la diversidad racial y cultural en el arte al interior de nuestra sociedad pluralista, al tiempo que paralelamente se afirma y enaltece el orgullo por el legado artístico propio y de cada individuo.

Finalmente, al estudiar cada una de las asignaturas artísticas del currículo [...], abordar cuestiones como el etnocentrismo, el sesgo, la estereotipia, el prejuicio, la discriminación y el racismo. (33)

Agrega dicho autor que la educación artística se produce dentro de contextos culturales específicos, y que en este sentido los maestros deberán preguntarse:

¿Cómo influyen de hecho diferentes experiencias culturales en la percepción que los individuos y los grupos tienen del arte?

¿Qué temas podrían estimular a los estudiantes para ver lo que hay de común en los roles y funciones del arte a través de las culturas?

Al centrar la mirada en las funciones comunes del arte ¿pueden conseguir los profesores hacer crecer la estima por la diversidad en el arte?

¿Cómo pueden plantear y enmarcar las cuestiones acerca del arte de manera que promuevan el debate de la unidad dentro de la diversidad? (33)

Por otra parte, Xabier Besalú (2010), de la Universidad de Girona, España, coloca las competencias frente a la educación intercultural y las habilidades cognitivas, afectivas, prácticas, comunicativas y sociales:

[...] Podríamos definir la competencia intercultural como el conjunto de habilidades cognitivas, afectivas y prácticas necesarias para vivir y actuar con autonomía y eficacia en un contexto social multicultural como el que se da en la mayor parte de nuestras ciudades y pueblos (Álvarez et al., 2005). Las habilidades cognitivas se refieren a la comprensión reflexiva y crítica de las propias prácticas culturales y del pluralismo cultural existente en el propio medio social y en el mundo (el valor y la funcionalidad de todas las producciones culturales; la imposibilidad de establecer fronteras fijas entre religiones, lenguas, costumbres, etc.; la conciencia de la diversidad interna inherente a cualquier grupo social...). Las habilidades afectivas remiten a la autoestima, a la capacidad para regular el propio comportamiento, a la escucha activa, a la apertura mental... Mientras que las habilidades prácticas serían, en su sentido más amplio, las habilidades co- 
municativas y sociales necesarias para vivir y convivir. Desde esta óptica, parece suficientemente claro que la competencia intercultural es necesaria para todo el alumnado, porque todos ellos deben aprender a vivir juntos en una sociedad plural desde muchos puntos de vista, compleja, conflictiva, democrática y libre. (3-5)

Elliot W. Eisner (2004), profesor de la Universidad de Stanford, afirma el papel de las artes en la transformación de la conciencia; y asegura que "la educación es el proceso de inventarnos a nosotros mismos". (27) Dicho autor vincula al arte con las funciones cognitivas como una manera de aprehender del mundo:

Las funciones cognitivas de las artes incluyen todos los procesos por medio de los cuales el organismo se hace consciente de su entorno o de su propia conciencia. Incluye las formas más complejas de resolución de problemas imaginables mediante los vuelos más elevados de la imaginación. Pensar, en cualquiera de sus manifestaciones, es un evento cognitivo.

[...] Una función cognitiva de las artes es ayudarnos a aprender a observar el mundo. [...] El arte nos ofrece las condiciones para que despertemos al mundo que nos rodea. En este sentido, las artes nos ofrecen una manera de conocer. 
BiBLIOGRAFÍA

Besalú, X. (2010) La educación intercultural y el currículo escolar, Primer Congreso Internacional en la Red sobre Interculturalidad y Educación. [en línea] <http:// www.congresointerculturalidad.net>, Recuperado 1 marzo 2010.

ChALmers, F. G. (2003) Arte, educación y diversidad cultural. Barcelona: Paidós, Arte y Educación.

Del VaL, J. (2009) Entender y comprender al otro. Programa Universitario México Nación Multicultural-unam, Ciudad Universitaria. [en línea] <http: www.nacionmulticultural.unam.mx/Portal/Central/EDITORIAL/documentos.html> Recuperado junio 2009

Dethlefsen, T. y Rüdiger D. (2000) La enfermedad como camino. España: Ediciones de Bolsillo, Plaza y Janés Editores.

EFLAND, A. D. (2002) Una historia de la educación del arte. Tendencias intelectuales y sociales en la enseñanza de las artes visuales. Barcelona: Paidós.

EISNER, E. W. (2004) El arte y la creación de la mente. Barcelona: Paidós.

FloRESCANO, E. et al. (2008) Cultura mexicana: revisión y prospectiva. México: TaurusSantillana.

García CAnClinI, N. (2005) La globalización imaginada. Argentina: Paidós.

García, B. et al. (2008) Modelo de evaluación de competencias docentes para la educación media y superior. Revista Iberoamericana de Evaluación Educativa (1), (3) [en línea] <http://www.rinace.net/riee/numeros/vol1-num3_e/art8.pdf>

GARDNer H. (1995) Cracking open the IQ Box. The American prospect. (invierno). (1993) Multiple Intelligences: The Theory in Practice. New York: Basic Books.

GIRÁLDEZ, A. (2007) Competencia cultural y artística. Madrid: Alianza Editorial.

Goleman, D. (2002) La inteligencia emocional. México: Punto de lectura.

Gran Diccionario Enciclopédico Ilustrado. (1975) México: Reader's Digest.

GutiérREz SÁenz, R. (1997) Introducción a la didáctica. México: Esfinge.

Hemsy de GaINZA, V. (1994) La transformación de la educación musical a las puertas del siglo XXı. Argentina: Guadalupe.

JOSEPH, R. (1993) The naked neurone: evolution and the languages of brain and Body. New York: Plenium Publishing.

KотULAK, R. (2003) El cerebro por dentro. Revolucionarios descubrimientos sobre el funcionamiento de nuestra mente. México: Diana.

LIPOVETSKy, G. (2008) La sociedad de la decepción. Entrevista con Bertrand Richard, Barcelona: Anagrama. 
Marco curricular para la Organización del Bachillerato Internacional, Normas para la implementación de los programas de Iво y aplicaciones concretas. (2007) México: Secretaría de Educación Pública. pp. 9-36, 63-70, 81-90, 144-155.

Marco Stiefl, B. (2008) Competencias básicas. Hacia un nuevo paradigma educativo. Madrid: Narcea.

MEGGS, Philip B. (2000) Historia del diseño gráfico. México: McGraw-Hill.

Pérez, A. (1997) Movimiento consciente en el entrenamiento actoral. Barcelona: Anagrama.

Perrenoud, P. (2004) Diez nuevas competencias para enseñar. Barcelona: Graó, México: Secretaría de Educación Pública, Biblioteca para la actualización del maestro.

RESTACK, R. (2005) Nuestro cerebro. Cómo la era moderna ha modificado nuestra mente. México: Urano.

SACRISTÁN, J. G. (2002) Educar y convivir en la cultura global. Madrid: Morata S. L.

Secretaría de Educación Pública, (2006) Resumen ejecutivo, Los objetivos de desarrollo del milenio en México. Informe de avance 2005. México: Secretaría de Educación Pública.

, Educación artística. Programas de estudio. (2008) México: Secretaría de Educación Pública. pp. 249-257, 259-262.

TuBino, F. (2005) La praxis de la interculturalidad en los Estados Nacionales latinoamericanos. Cuadernos Interculturales. Universidad de Valparaíso: Viña del Mar Chile, julio-diciembre, (3), (005).

Valencia Rojas, A. J. et al. (2009) México en el nuevo milenio: la redefinición de una nación pluriétnica y multicultural. Programa Universitario México Nación Multicultural-unam, Ciudad Universitaria, [en línea] <http: www.nacionmulticultural.unam.mx/Portal/Central/editorial/documentos.html> Recuperado junio de 2009. 

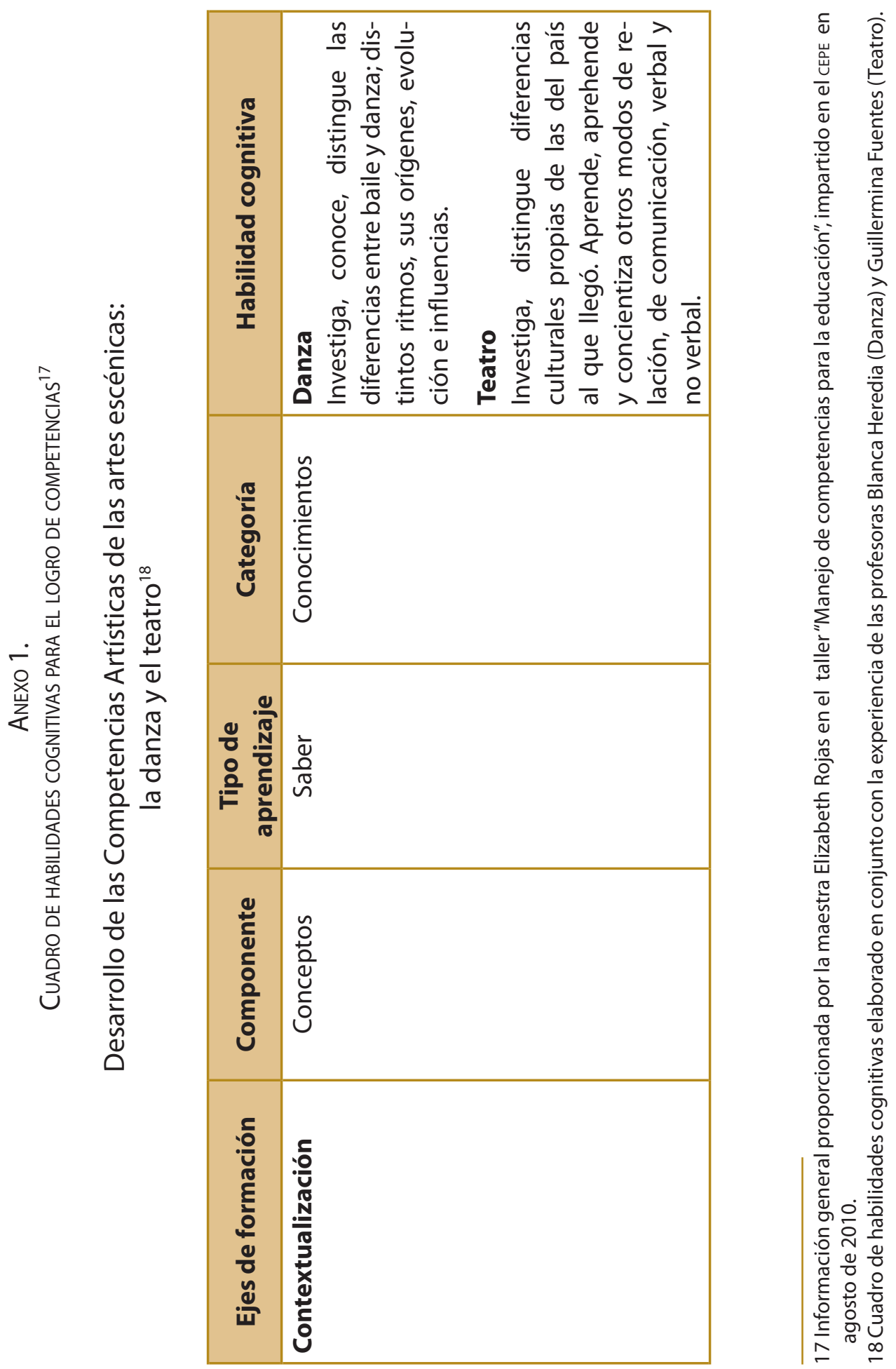


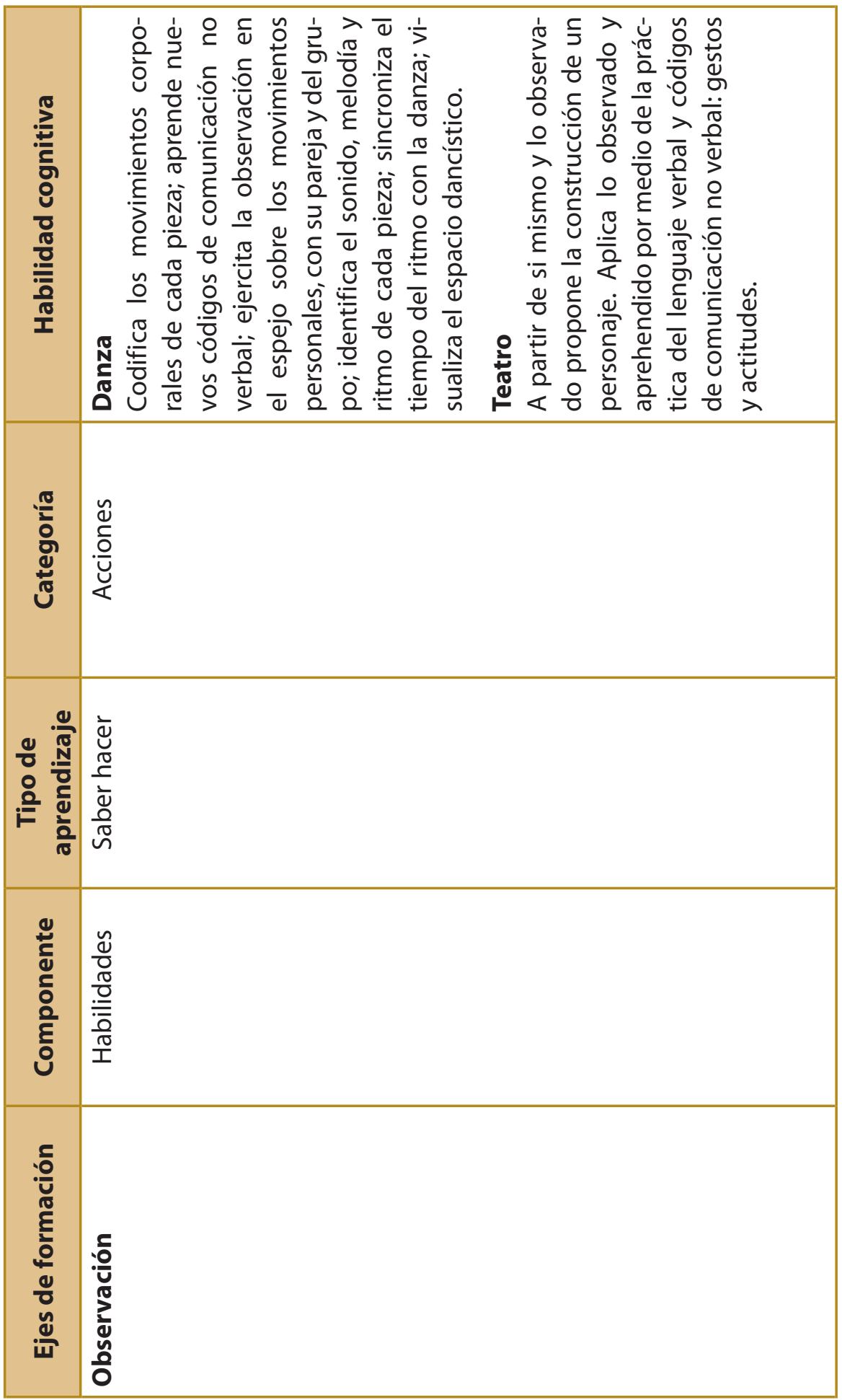




\begin{tabular}{|c|c|c|}
\hline 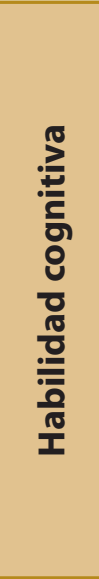 & 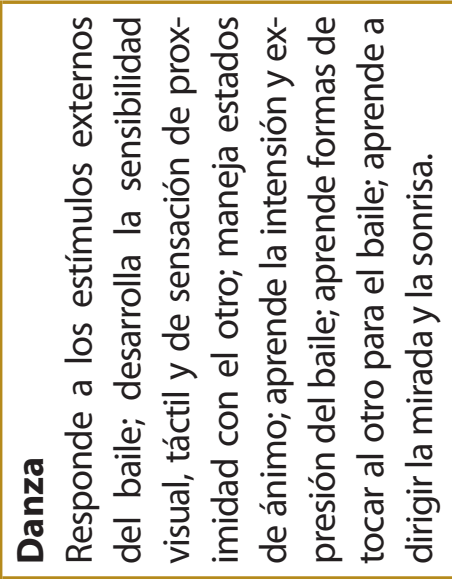 & 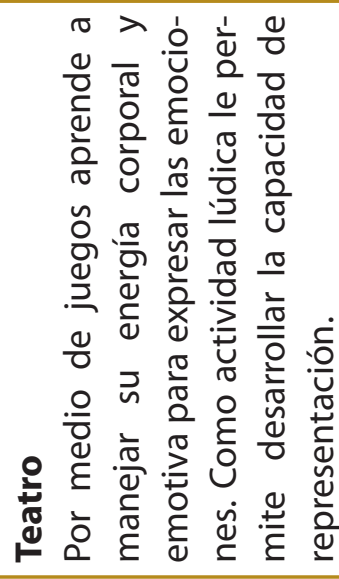 \\
\hline 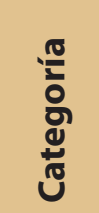 & 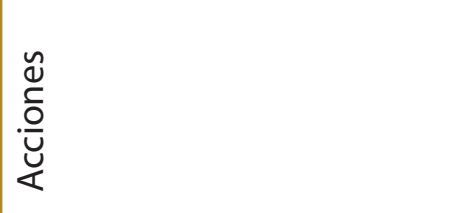 & \\
\hline 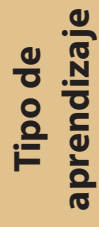 & 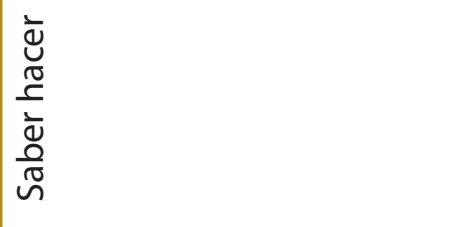 & \\
\hline 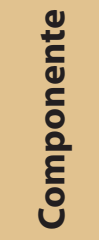 & $\begin{array}{l}\frac{n}{0} \\
\frac{0}{0} \\
\frac{0}{0} \\
\frac{0}{\overline{0}} \\
\frac{\pi}{1} \\
\frac{\pi}{1}\end{array}$ & \\
\hline 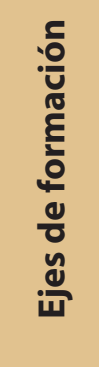 & 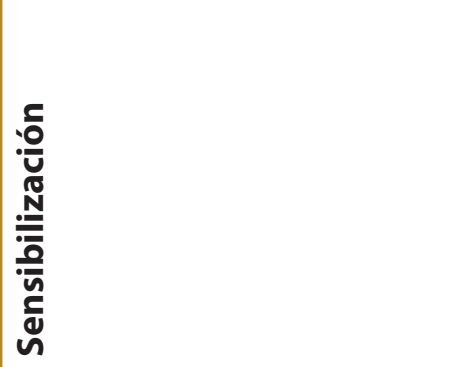 & \\
\hline
\end{tabular}




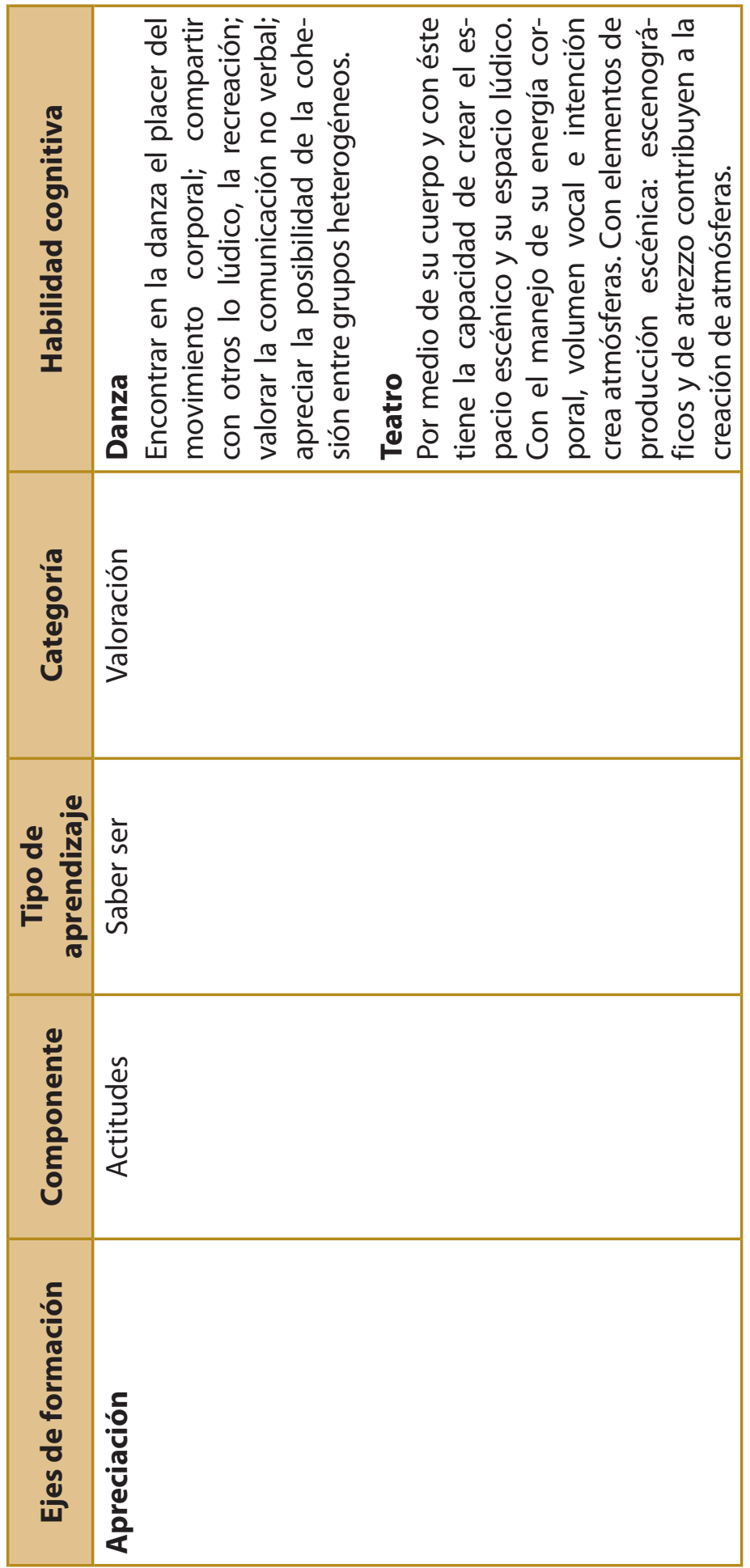




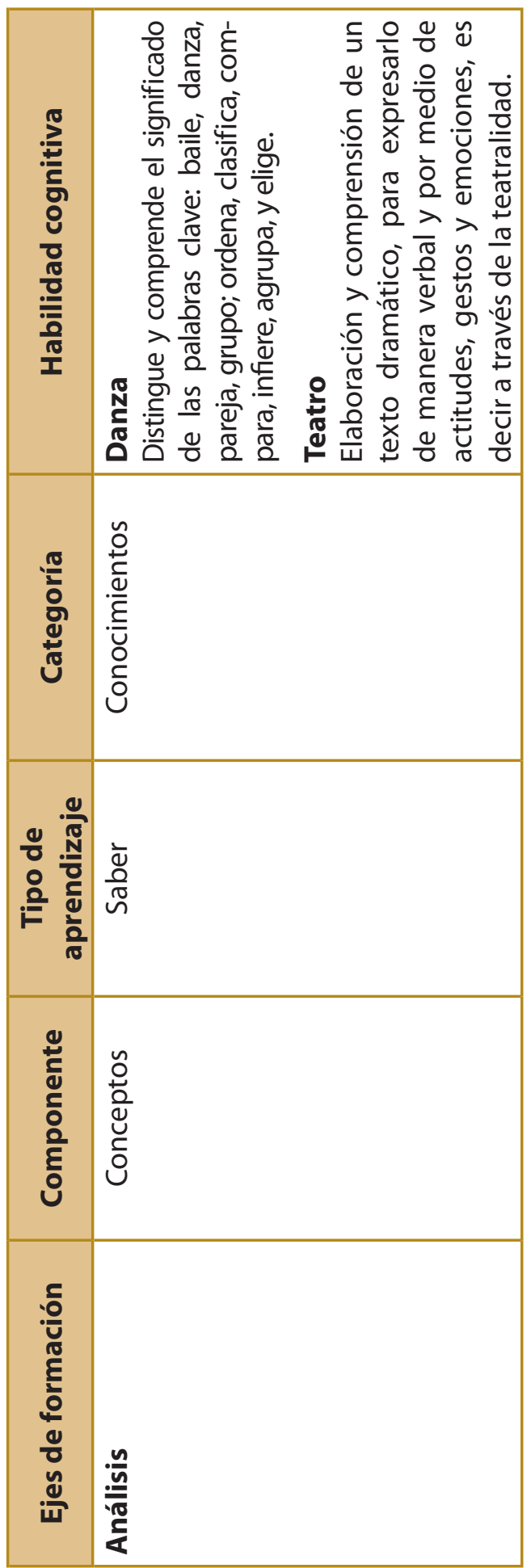




\begin{tabular}{|c|c|c|}
\hline 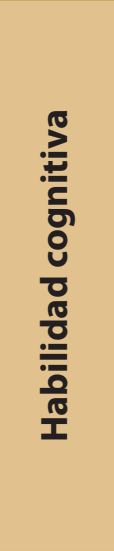 & 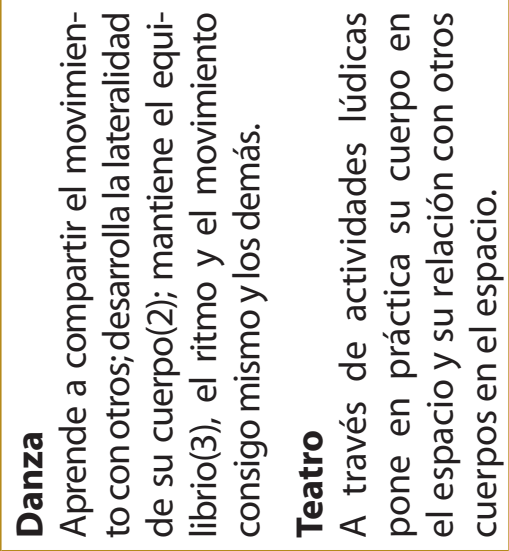 & 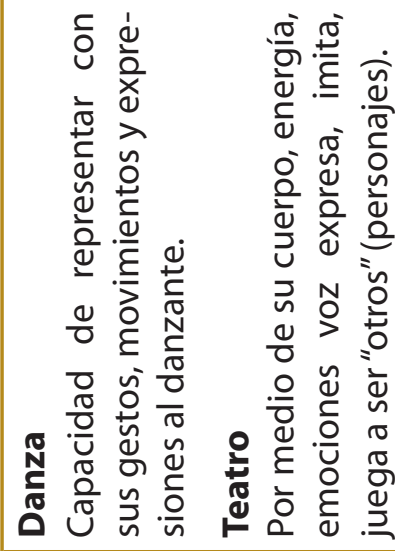 \\
\hline 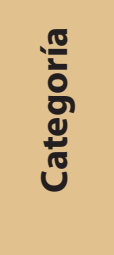 & 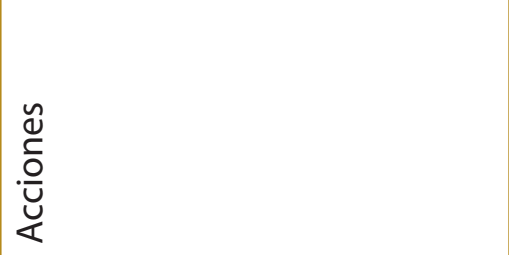 & 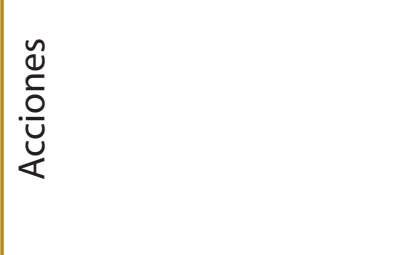 \\
\hline 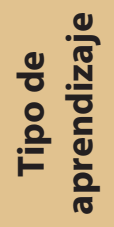 & 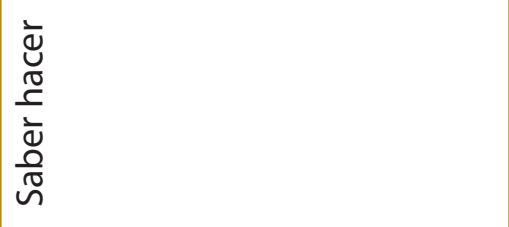 & 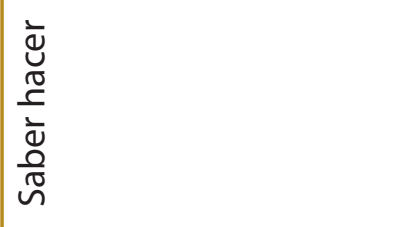 \\
\hline 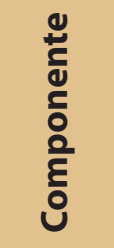 & $\begin{array}{l}\frac{y}{0} \\
\frac{\pi}{0} \\
\frac{0}{0} \\
\frac{0}{0} \\
\frac{\pi}{1}\end{array}$ & $\begin{array}{l}\frac{\tilde{y}}{0} \\
\frac{0}{0} \\
\frac{0}{0} \\
\frac{0}{10} \\
\frac{\pi}{1}\end{array}$ \\
\hline 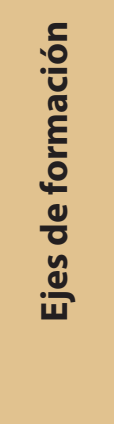 & 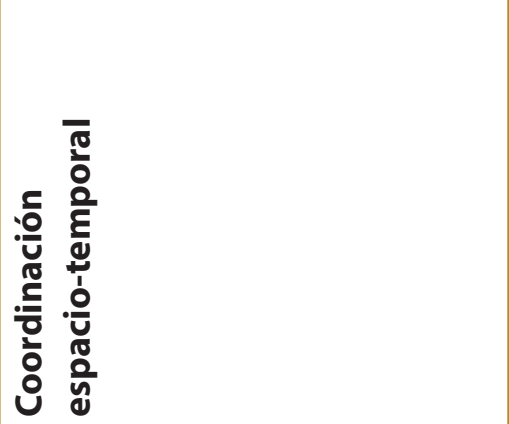 & $\frac{\stackrel{n}{y}}{\stackrel{\xi}{y}}$ \\
\hline
\end{tabular}




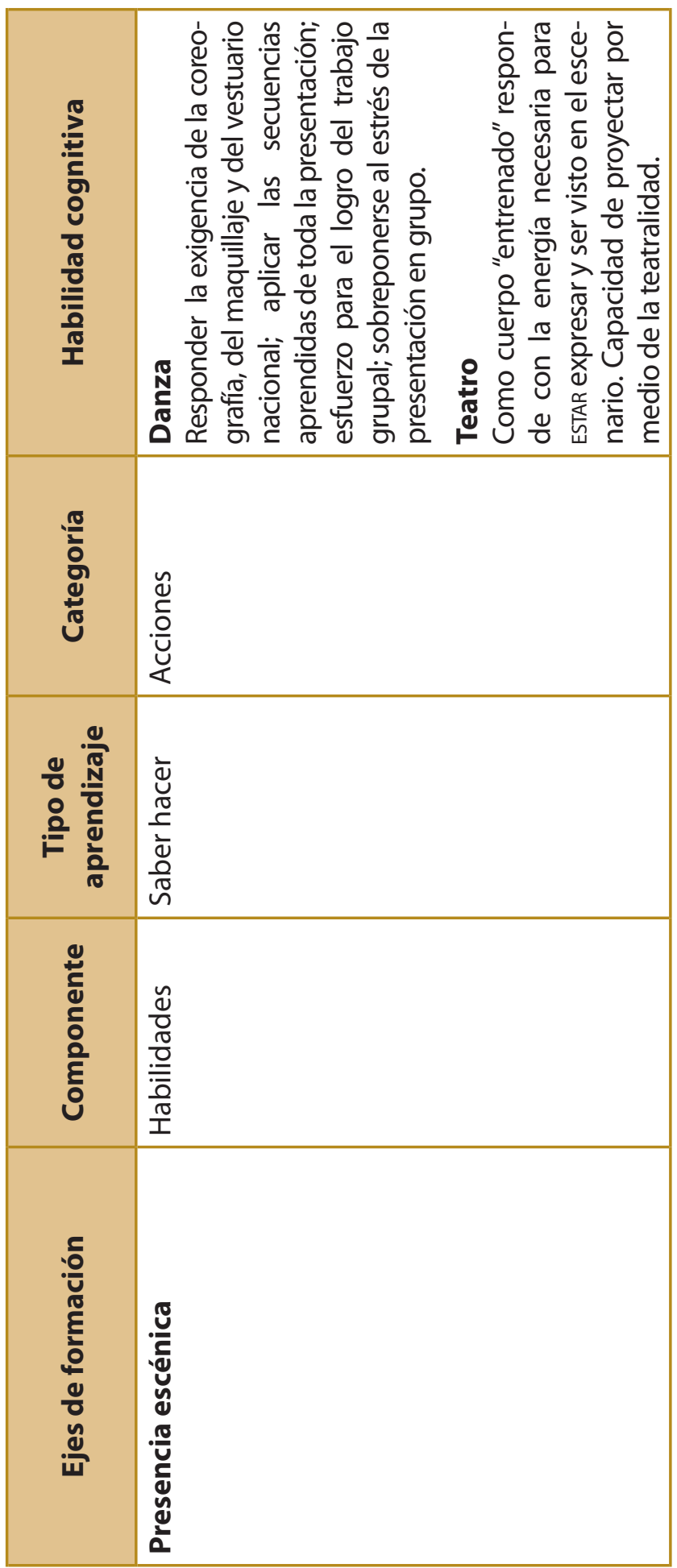




\begin{tabular}{|c|c|c|}
\hline 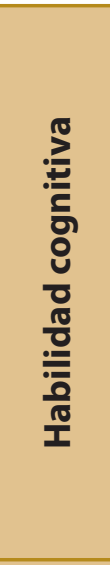 & 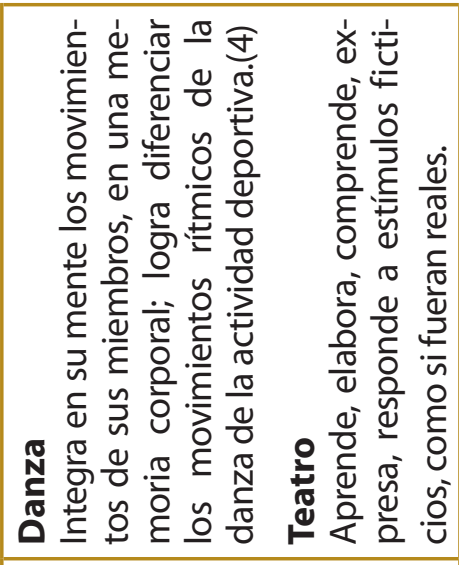 & 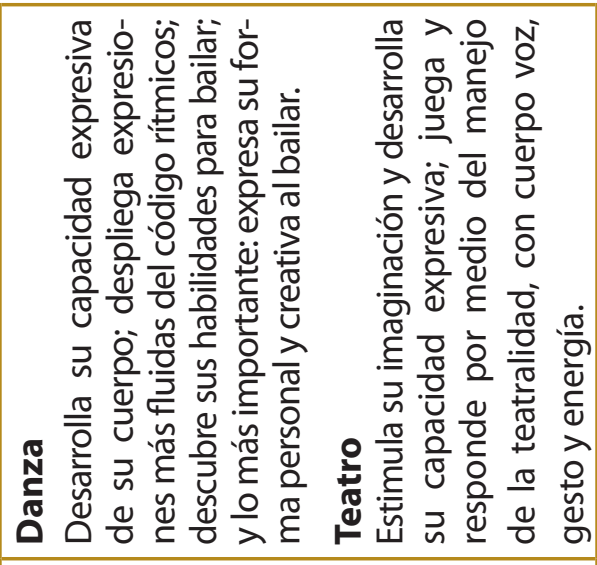 \\
\hline 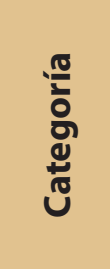 & 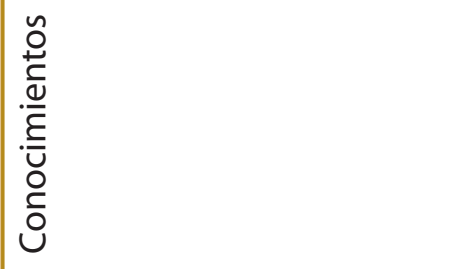 & $\begin{array}{l}\frac{\pi}{0} \\
\frac{0}{0} \\
\frac{0}{0} \\
\frac{0}{2}\end{array}$ \\
\hline 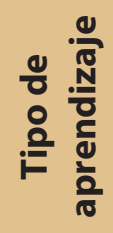 & $\begin{array}{l}\overline{\bar{d}} \\
\frac{0}{\overline{0}} \\
\sim\end{array}$ & 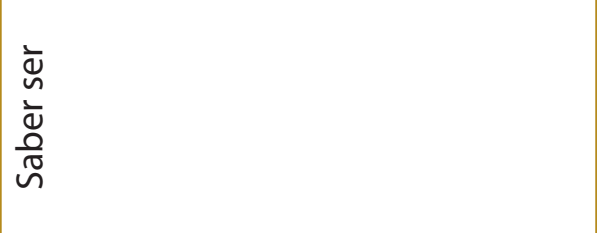 \\
\hline 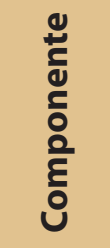 & 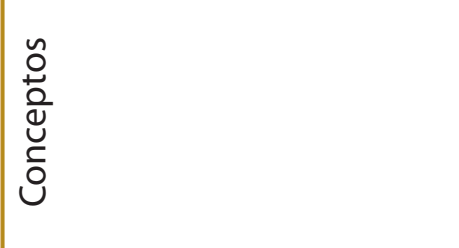 & 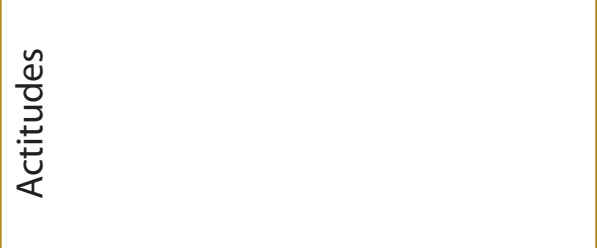 \\
\hline 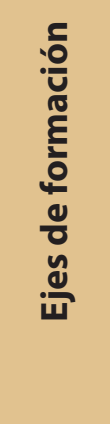 & 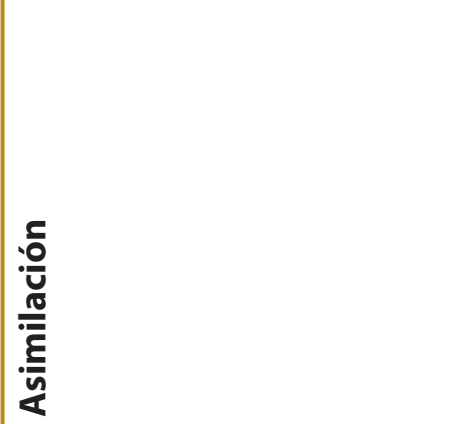 & 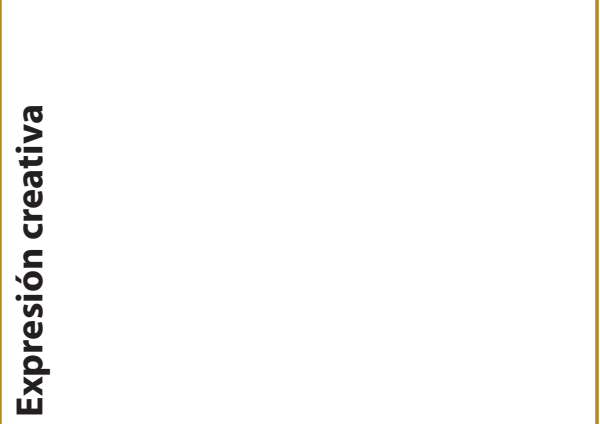 \\
\hline
\end{tabular}




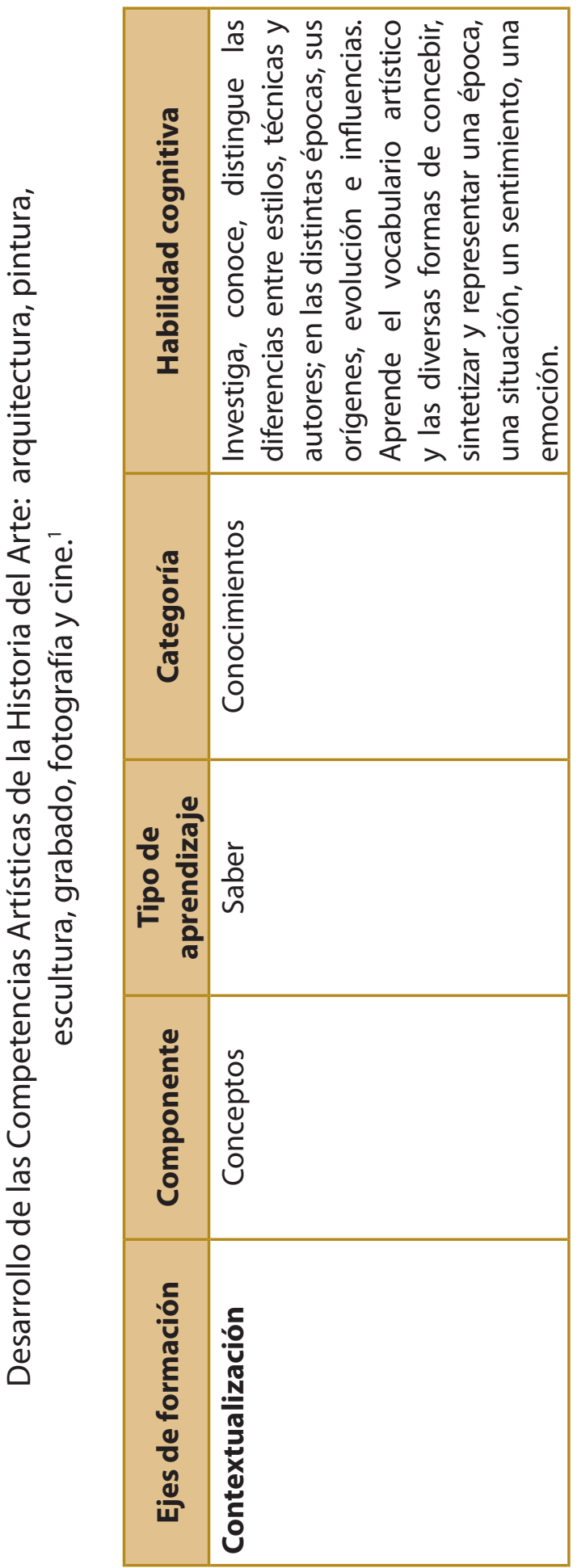




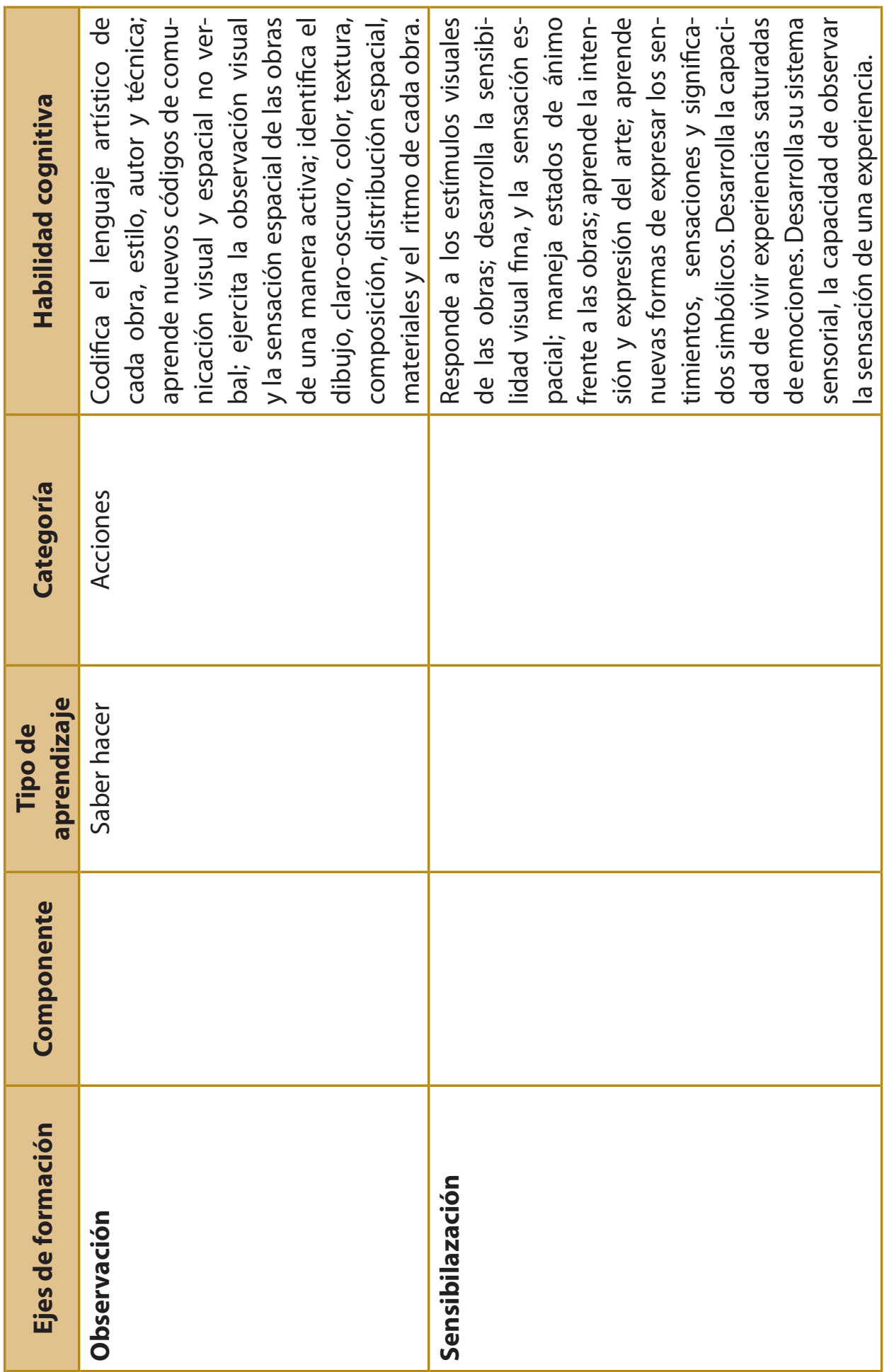




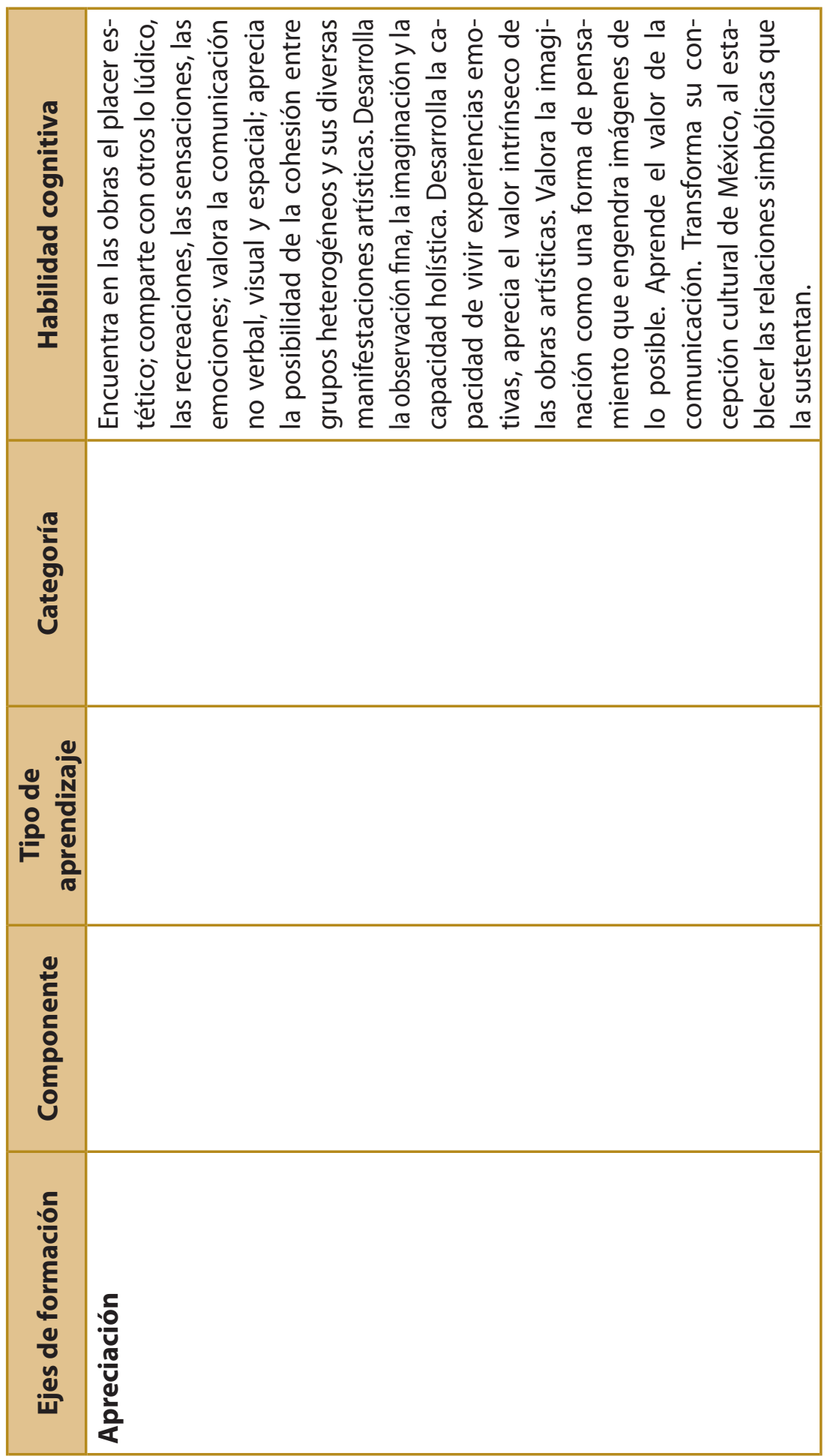




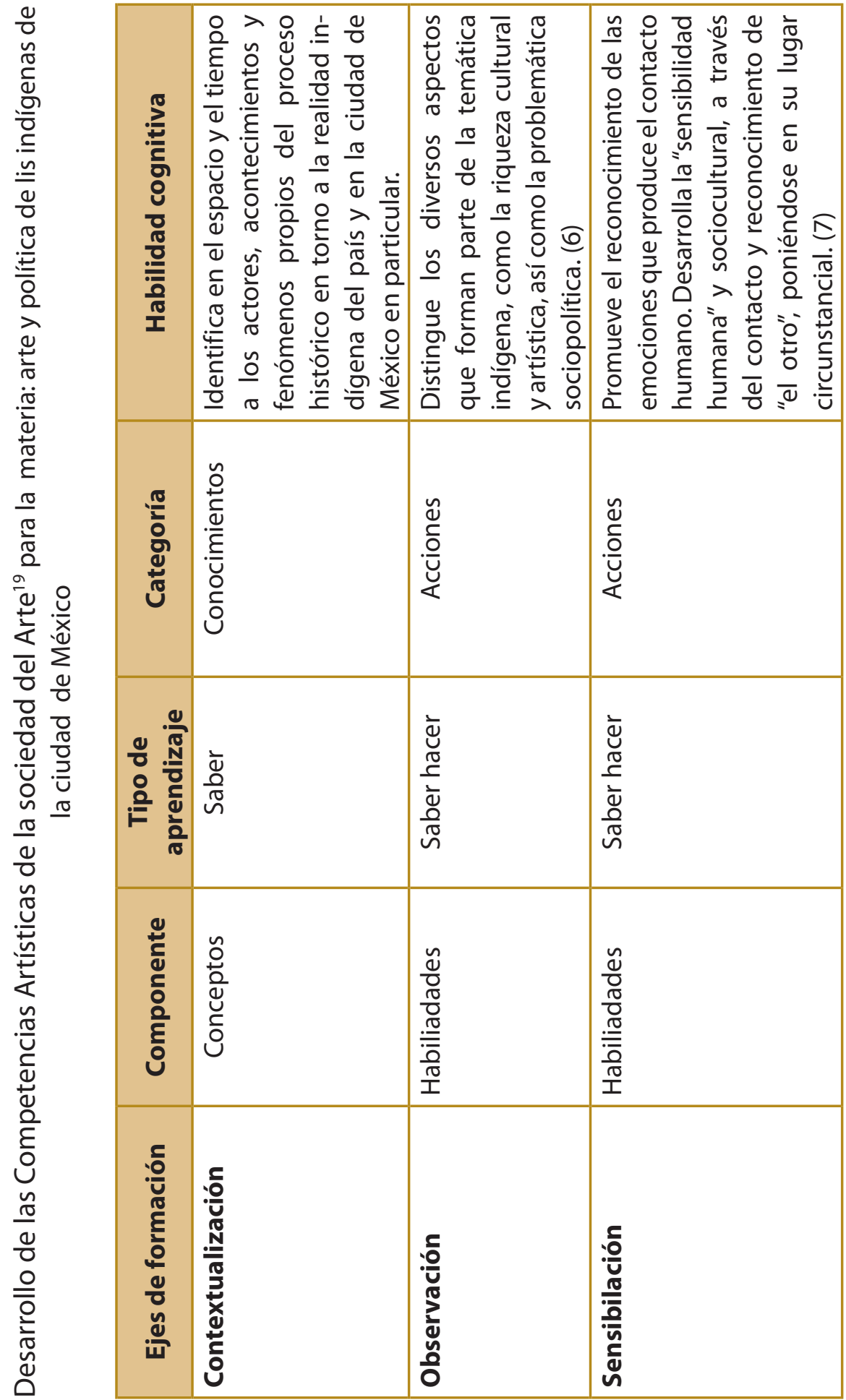




\begin{tabular}{|c|c|c|}
\hline 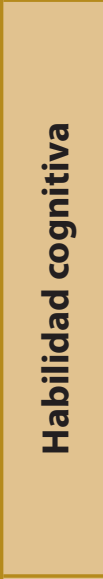 & 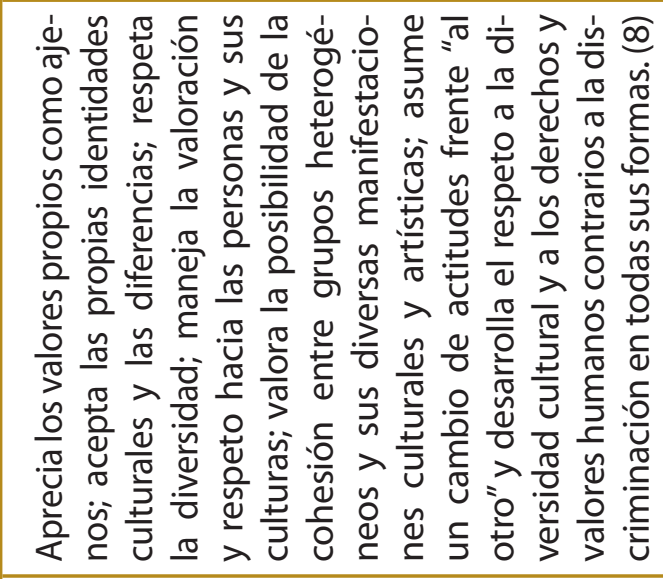 & 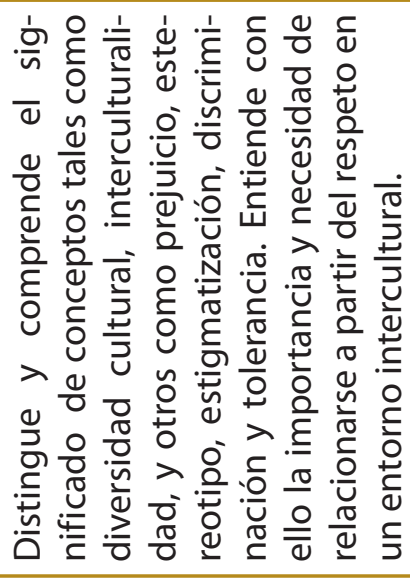 \\
\hline 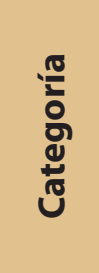 & 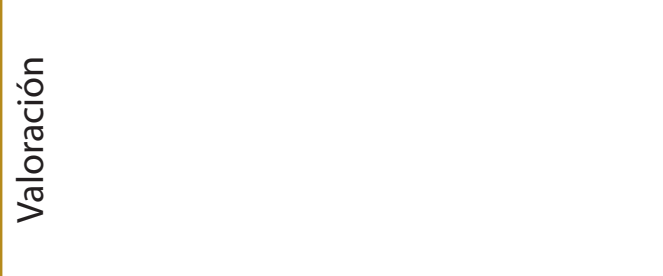 & 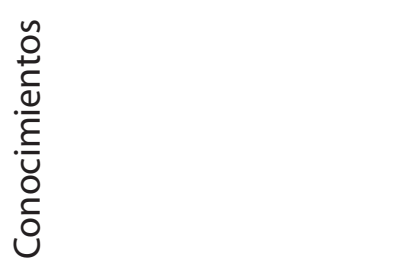 \\
\hline 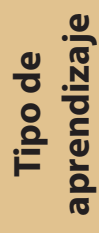 & 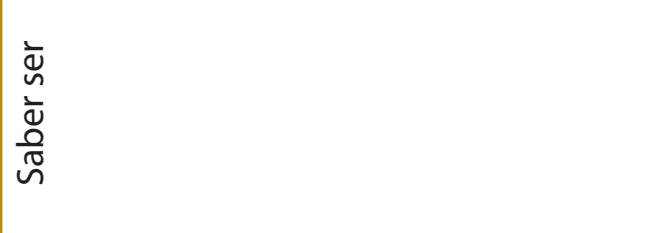 & $\begin{array}{l}\bar{\varpi} \\
\frac{0}{\tilde{D}} \\
\text { ज }\end{array}$ \\
\hline 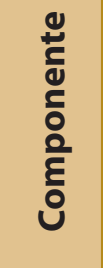 & 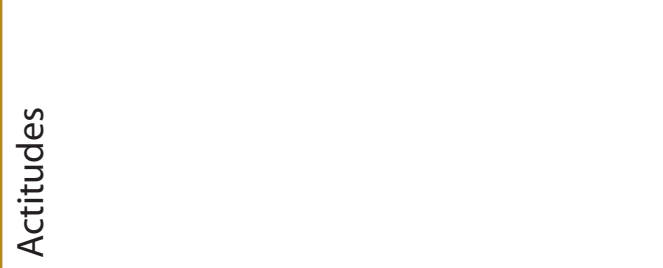 & 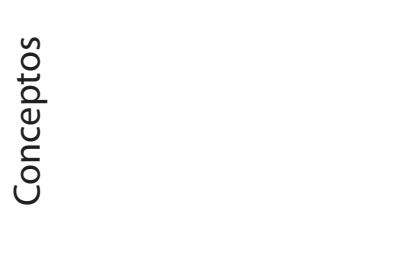 \\
\hline 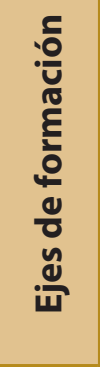 & 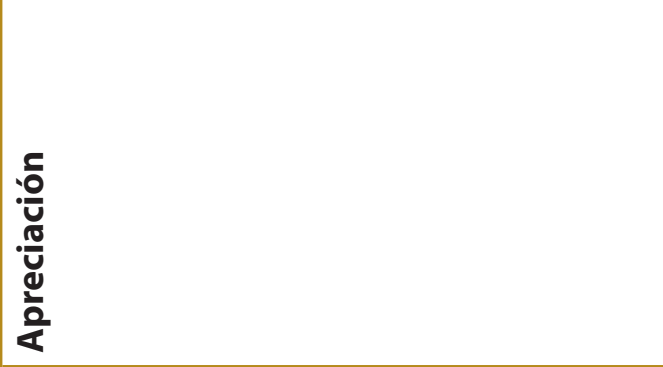 & 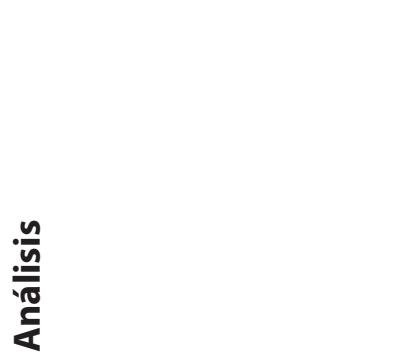 \\
\hline
\end{tabular}


Anexo 2. Algunas experiencias y reflexiones de los cursos del Departamento de Arte, COMO EJEMPLO DE LAS COMPETENCIAS Y DE LA INTERCULTURALIDAD TRABAJADAS EN CLASE.

\section{Ejemplo No. 1}

En una sesión de un curso del área de sociología del $a r t e,{ }^{20}$ se abordó el tema de la discriminación. Dicha sesión se dividió en cuatro partes: En la primera se reflexionó específicamente sobre la discriminación que existe en México hacia los indígenas, no sólo hacia su persona, sino también hacia su cultura y el menosprecio a sus expresiones artísticas o artesanales. El profesor, los alumnos extranjeros y mexicanos, y una invitada indígena mazahua, analizaron e intercambiaron puntos de vista al respecto, tocándose, además, el tema de los estereotipos sociales y culturales.

En la segunda parte, se analizaron otras formas de discriminación en México, como la que se ejerce sobre las mujeres, las personas con alguna discapacidad, los adultos mayores, los homosexuales, los pobres (los llamados grupos "en desventaja social" o "históricamente vulnerados entre otros").

En la tercera parte, los alumnos extranjeros mediante un ejercicio de asociación hablaron de las formas de discriminación que se viven en sus propios países, y en otros lugares del mundo.

En la última parte de la sesión, los alumnos se manifestaron contrarios a la discriminación, y concluyeron sobre la importancia del respeto y valoración a las diferencias, a la diversidad cultural y a otras formas de la diversidad humana.

Finalmente, la invitada indígena habló de sus propias experiencias frente a la discriminación. Compartió que cuando se viste de manera semejante a la mayoría de los habitantes de la ciudad de México las personas la tratan de forma diferente, incluso, le han ofrecido el asiento en el transporte público, mientras que cuando viste su traje indígena nunca le ofrecen el lugar, al contrario, en muchas ocasiones la empujan, la maltratan o se mofan de ella. La mujer expresó al grupo: “Es algo que no entiendo, ¡si soy la misma!, ¡soy la misma mujer con cualquiera que sea mi vestido!, ¿por qué cuando me visto con mi traje no son amables conmigo?, ¿por qué me tratan mal cuando se dan cuenta que soy indígena?"

La mujer derramó algunas lágrimas, enseguida una alumna extranjera se levantó de su pupitre, tomó de las manos a la mujer indígena, la puso en pie y la abrazó fuertemente. Lloraron las dos abrazadas. Y concluyó la sesión con una sonrisa de ambas y con un agradecimiento mutuo. La mujer indígena manifestó

20 Del curso Arte y Política de los Indígenas de la Ciudad de México, impartido por el profesor Gerardo Chavero. 


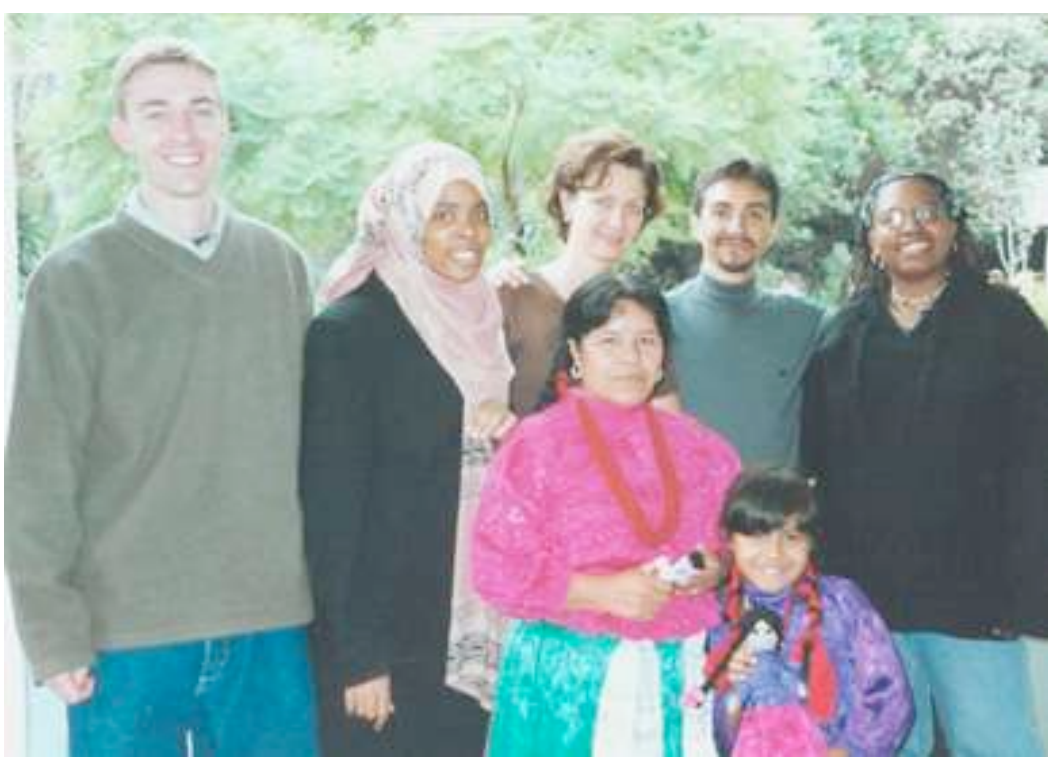

que para ella fue una experiencia positiva y enriquecedora, coincidiendo con la apreciación de los alumnos.

Esta experiencia de "sensibilidad humana" e intercambio intercultural que se vivió en el salón de clase, desde luego no se quedó en éste, sino que se llevó a cabo la transferencia ${ }^{21}$ de dicha experiencia y aprendizaje en otros contextos fuera del aula; primero en otros espacios aquí en México, y después —en el caso de los alumnos extranjeros - en sus propios países de origen, según comentaron lo llevarían a cabo. Además, señalaron que no sólo sería un cambio de su propia actitud con lo asimilado en clase, pues intentarían influir en otras personas en ese mismo sentido, lo mismo señalaron los alumnos mexicanos. Incluso, no sólo se generó en los alumnos el rechazo a la discriminación hacia los indígenas en México, y la valoración y respeto a las culturas y personas indígenas; sino que al mismo tiempo, se manifestaron contrarios a toda forma de discriminación en México y en el mundo, expresando su posición de valoración y respeto a la diversidad humana.

Esta experiencia nos mostró el papel transformativo ${ }^{22}$ que puede propiciar el proceso académico en las ideas, sentimientos, las actitudes y el comportamiento de los alumnos en diversos espacios, así como su efecto multiplicador. Se trabajó, en este sentido, en torno a competencias como la Revisión crítica de actitudes y valores humanos, así como en la interculturalidad.

21 Según Berta Marco (2008), "la competencia se juega en la capacidad de movilizar conocimientos y transferir los aprendizajes desde las situaciones de aula a las situaciones de vida".

22 De acuerdo con Fidel Tubino (2005) (95), la educación intercultural busca "......] transformar las estructuras simbólicas sobre las que se construyen las relaciones sociales entre los diferentes". 
Ejemplo No. $2^{23}$

Alumna: Diep, vietnamita, otoño de 2008.

El ejercicio pedía su apreciación sobre el panorama musical de México y un ejemplo del instrumento musical tradicional de su país.

De todos los temas que hemos estudiado en la clase del arte, el que me gusta más es la música. Primero, es un tema muy vivo con imágenes y sonidos. Pues, tengo oportunidad de dar un recorrido por los orígenes de la música mexicana. Lo que pasa es que antes sólo he conocido su música a través de los mariachis. Después de este recorrido, he descubierto que México posee diversos tipos de música. Además, recibe muchas influencias de distintas culturas: europea, americana y africana. Así que la música mexicana cuenta con características muy peculiares.

En cuanto a los tipos de instrumentos musicales, me doy cuenta de que son productos con materiales extraídos de la naturaleza. Por otra parte, estos instrumentos son símbolos y reflejan, de un modo u otro, una parte de la cultura mexicana. Por ejemplo, hay instrumentos que se hacen de tortugas -un símbolo de la dualidad. El instrumento que me llama mucho la atención es la trompeta de caracol. Como sabemos, el caracol tiene un significado muy importante en la vida de los mexicanos, ya que simboliza la fertilidad. En mi país, también se utilizan los caracoles para hacer joyas y por supuesto, un tipo de instrumento musical. La diferencia entre el mexicano y el vietnamita es que los mexicanos lo utilizan como una trompeta, en cambio, los vietnamitas lo utilizamos para escuchar el sonido emitido del caracol.

Hablando de la comparación entre la música mexicana y la vietnamita, podemos llegar a un acuerdo en que ambas utilizan los materiales como madera, piel o piedra, es decir, los materiales provienen de la naturaleza. Por lo tanto, el sonido que producen estos instrumentos es muy original y cercano a la vida cotidiana.

En mi país, los pueblos indígenas en el centro crean un tipo de instrumento musical muy especial que se llama " $T$ ' rưng". Se hace de bambú, una especie de árbol típico de Vietnam. Se utilizan dos baquetas para tocar. Lo interesante es que el sonido que produce es similar al sonido de la naturaleza de las zonas montañosas donde viven estos pueblos. En otras palabras, es un conjunto de sonidos: pájaros, manantiales y el eco de las montañas. Otro instrumento musical que posee sólo mi país es "dan bau". Se trata de un instrumento de una única cuerda, pero se puede producir todas las notas musicales. Su sonido es triste, el cual nos trae una sensación de nostalgia.

23 Ejercicio llevado a cabo en el curso "Arte mexicano en 100 imágenes" Intermedio 2, impartido por la profesora Silvia Fernández. 

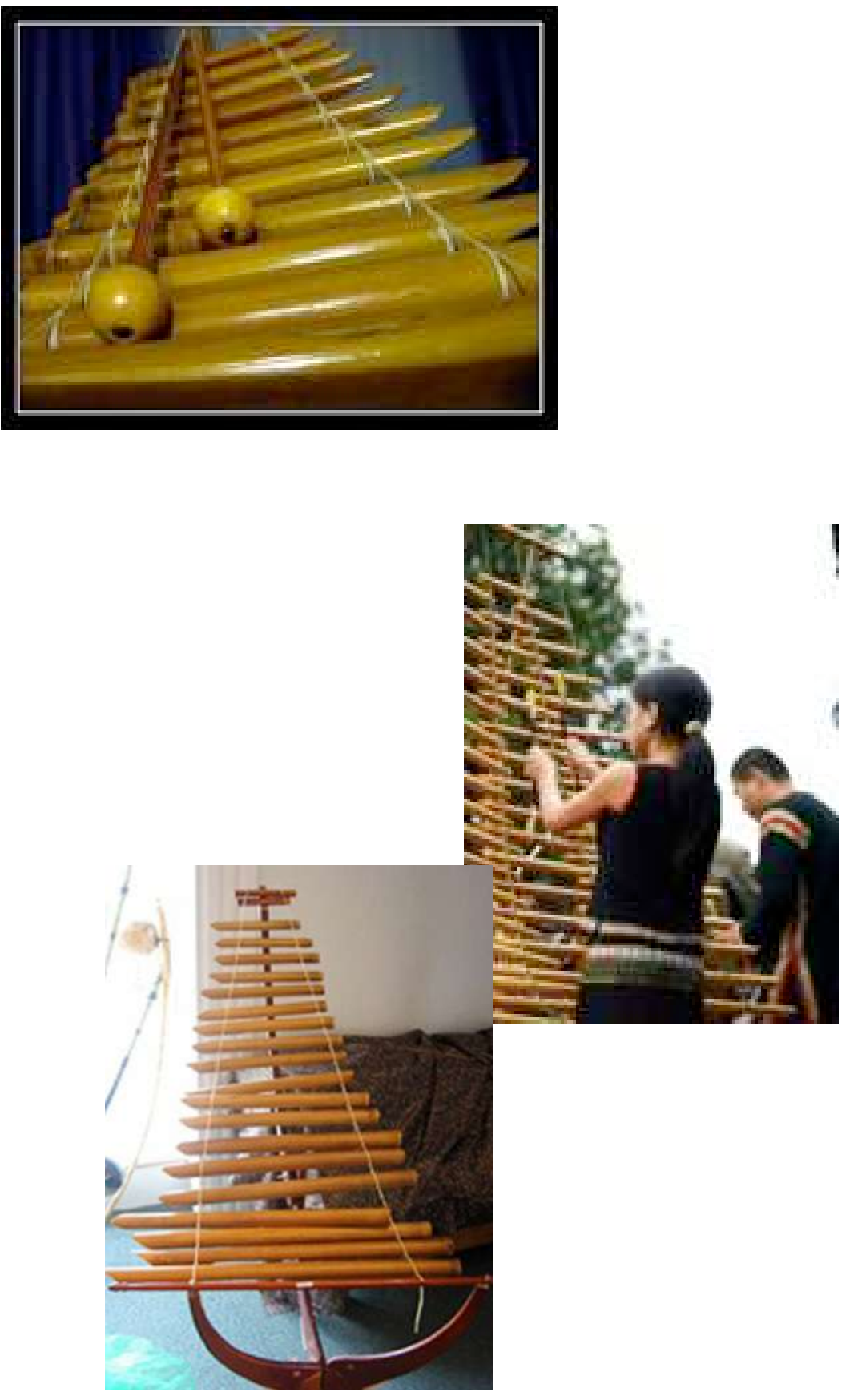
En una palabra, música es una parte muy importante en nuestra vida, pues la tocamos en las fiestas, en la vida cotidiana para relajarnos, incluso, la música de cada país representa una parte de su cultura.

El ejercicio demuestra con claridad cómo la alumna aumentó su vocabulario con la palabra "baquetas", cambió el estereotipo de que la música mexicana es sólo de marichis y aplicó su aprendizaje en un intercambio intercultural que de acuerdo al último párrafo fue significativo para ella.

Ejemplo No. $3^{24}$

Un poco de todo

Christina Alexander ${ }^{25}$

Estas cuatro obras son muy diferentes pero tienen algo en común, juntan al público en espacios variados para que pensemos, sintamos y confrontemos mundos reales o fantásticos. Para mí fue una experiencia increíble. Sí. Es posible que yo no haya entendido todo lo que pasaba en el escenario, pero no importa porque entendí bastante. A pesar de que no hablo el español con fluidez me fascinaron las obras, los centros culturales que no había visitado antes y las audiencias variadas. Y sobre todo la sorpresa de que yo entendí las obras, a pesar de que no comprendí algunas cosas culturales. Aunque el teatro refleja la cultura también es universal. Tenía miedo de ir al teatro en español pero me encantó y ahora tengo ganas de seguir asistiendo. Puedo aprovechar esta expresión cultural, profunda y rica, de las culturas hispanohablantes, la del teatro.

Otra clase que recuerdo mucho, era la clase de teatro. Guillermina Fuentes, la maestra, tenía la genial idea de ir a ver varias obras de teatro y comentarlas después en clase. De esta manera, tuve la posibilidad de ver y apreciar el teatro mexicano. Es más, por primera vez en mi vida, el teatro me apasionó.

Ejemplo No. $4^{26}$

Experiencia en la clase de Danza Tradicional, con un grupo de doce alumnas extranjeras y dos alumnos (uno de básico-1 y el segundo de nivel avanzado).

Comenzamos la primera semana de clases a conocernos y a trabajar calentamiento, estiramiento y la técnica básica de la Danza Tradicional. Noté que a uno

24 Texto de la profesora Guillermina Fuentes, de las materias de Teatro y Expresión corporal. 25 Texto publicado en Flores de Nieve, núm. 14. Christina Alexander es estudiante de Teatro vivo, en el Centro de Enseñanza para Extranjeros.

26 Texto de la profesora Blanca Jazmín Heredia, del curso de danza tradicional. 
de mis alumnos le costaba un mayor trabajo corporal que al resto del grupo, sin interferir en él la comprensión de la lengua. Incluso, noté en algunas ocasiones su queja porque no le salían los pasos que aprendían, que no le salían porque no tenía los botines necesarios, porque eran pisadas imposibles para extranjeros, pero no declinaba, su asistencia a clase.

El grupo fue paciente y cooperativo apoyándolo en la práctica. Y él sumamente persistente practicaba en cada momento libre que podía. Así, él al igual que todos, fuimos viendo su progreso dancístico e incluso, su cambio de actitud y de percepción que el folklore mexicano "es difícil e imposible para un extranjero". Fue uno de los más contentos y satisfechos en la presentación de fin de cursos que se da en el auditorio del CEPE. Tomó un curso más de danza tradicional y cuando terminó su último nivel y regresó a su país de origen, me dijo que iba a buscar restaurantes mexicanos para bailar allá danza tradicional y enseñar lo que aprendió aquí. Supe que se metió a un grupo de Danza de Concheros y buscaba actividades para conocer más el folklore. Y él, al igual que el resto del grupo me confiaron que fue para ellos una experiencia inolvidable, bailar con la ropa tradicional de México, los aplausos y felicitaciones de sus amigos, y vivir el movimiento y riqueza cultural de la danza tradicional, que sin duda van a compartir con sus conocidos.

\section{Ejemplo No. $5^{27}$}

I. Las materias de arte nos permiten enseñar códigos de percepción estética que se formularon y enriquecieron desde el inicio de nuestra cultura mexicana, que al trascender y acumularse hasta nuestros días se convierten en fuente de conocimiento visual e intelectual que se le ofrece al estudiante extranjero, paralelamente a su instrucción en el idioma español.

Los productos estéticos, las obras del arte mexicano, no deben ser tomadas como meras ilustraciones de la enseñanza de la gramática o la pragmática de la comunicación descriptiva en la vida cotidiana.

II. En la sesión de arte impartida en el CEPE se debe buscar facilitar la experiencia estética, esto es, percepción-decodificación-desarrollar la percepción dentro de los límites y condiciones que impone nuestra historia cultural (donde historia patria, sociedad y religión convergen y el arte las codifica). Esta experiencia estética le permitirá al alumno apropiarse de un objeto de estudio integral (información-signos plásticos-ideas-interpretaciones a la luz de la sociedad). Tal es la flexibilidad de dicha experiencia estética que no está determinada por el avance y eficacia de la práctica de la lengua española.

27 Reflexiones del profesor Juan Carlos Campuzano, de la materia: El arte de la posmodernidad. 
III. En cuanto al desarrollo de competencias intelectuales, y el adecuado diseño de las herramientas para el aprendizaje, —en mi caso concreto- la enseñanza del arte de finales del siglo xx y del arte contemporáneo me impone un reto significativo y novedoso, en una etapa particular de la historia del arte en la que las obras ya no son objetos valiosos guardados en vitrinas. En una era en la que el museo tradicional ya es inoperante.

A partir del arte conceptual de los años sesenta, la información en estado puro se convierte en arte. De las ideas a los soportes informativos hoy el arte es discusión intelectual más que fabricación de objetos.

Juzgando a partir de las competencias intelectuales, aparte de que el alumno aprecie la superación del canon de la "belleza" de los objetos artísticos, con el arte contemporáneo, el manejo y uso de información representa ya una manera de apreciación intelectual del arte de nuestro tiempo.

Existen artistas que sacan a la luz sus obras a través de vehículos informativos e intelectuales que le presentan al espectador enigmas y asuntos de resolución de problemas: hoy que está tan en boga el paradigma del aprendizaje a través del "problem-solving". Lo que nos viene de Estados Unidos es prueba de ello.

Y por último, la obra de arte contemporánea ya no exige al presentarse a un público real una opinión sobre lo "bonito" o lo placentero; el arte contemporáneo requiere para crecer y desarrollarse de juicios críticos. Lo cual entraña un desafío para el docente ya que el público, los alumnos, no están acostumbrados a que a partir del arte se les solicite adoptar una postura y emitir un juicio verdadero, porque eso asusta a los alumnos (sobre todo a los mexicanos, que en mucho siguen en la inercia de que el universo del arte es solamente un universo de "placer de los sentidos"). Considero que explicar y apreciar la obra de arte contemporánea es un reto de competencia intelectual para los alumnos. 
